\title{
Threefold increase in marine-terminating outlet glacier retreat rates across the Atlantic Arctic: 1992-2010
}

\author{
J. Rachel CARR, ${ }^{1}$ Chris. R. STOKES, ${ }^{2}$ Andreas VIELI ${ }^{3}$ \\ ${ }^{1}$ Department of Geography, Newcastle University, Newcastle, UK \\ E-mail: rachel.carr@newcastle.ac.uk \\ ${ }^{2}$ Department of Geography, Durham University, Durham, UK \\ ${ }^{3}$ Department of Geography, University of Zurich, Zurich, Switzerland
}

\begin{abstract}
Accelerated discharge through marine-terminating outlet glaciers has been a key component of the rapid mass loss from Arctic glaciers since the 1990s. However, glacier retreat and its climatic controls have not been assessed at the pan-Arctic scale. Consequently, the spatial and temporal variability in the magnitude of retreat, and the possible drivers are uncertain. Here we use remotely sensed data acquired over 273 outlet glaciers, located across the entire Atlantic Arctic (i.e. areas potentially influenced by North Atlantic climate and/or ocean conditions, specifically: Greenland, Novaya Zemlya, Franz Josef Land and Svalbard), to demonstrate high-magnitude, accelerating and near-ubiquitous retreat between 1992 and 2010. Overall, mean retreat rates increased by a factor of 3.5 between 1992 and $2000\left(-30.5 \mathrm{~m} \mathrm{a}^{-1}\right)$ and $2000-10\left(-105.8 \mathrm{~m} \mathrm{a}^{-1}\right)$, with $97 \%$ of the study glaciers retreating during the latter period. The Retreat was greatest in northern, western and south-eastern Greenland and also increased substantially on the Barents Sea coast of Novaya Zemlya. Glacier retreat showed no significant or consistent relationship with summer air temperatures at decadal timescales. The rate of frontal position change showed a significant, but weak, correlation with changes in sea-ice concentrations. We highlight large variations in retreat rates within regions and suggest that fjord topography plays an important role. We conclude that marine-terminating Arctic outlet glaciers show a common response of rapid and accelerating retreat at decadal timescales.
\end{abstract}

Keywords: Arctic glaciology, atmosphere/ice/ocean interactions, climate change, glacier monitoring, remote sensing

\section{INTRODUCTION}

Atmospheric warming in the Arctic is forecast to far exceed the global average, reaching $2.2-8.3^{\circ} \mathrm{C}$ by 2100 (IPCC, 2013). As a result, Arctic ice masses are expected to rapidly lose mass and contribute substantially to sea-level rise. During the past two decades, loss of land ice in the Arctic has been dramatic, and substantial losses were recorded across every major Arctic ice mass between 2003 and 2009 (Gardner and others, 2013). The Greenland ice sheet alone has contributed substantially to global sea-level rise, with recent estimates giving values of $\sim 0.47 \pm 0.23 \mathrm{~mm} \mathrm{a}^{-1}$ between 1991 and 2015 (van den Broeke and others, 2016), $0.6 \pm 0.1 \mathrm{~mm} \mathrm{a}^{-1}$ between 2000 and 2010 (Fürst and others, 2015) and $0.73 \mathrm{~mm} \mathrm{a}^{-1}$ between 2007 and 2011 (Andersen and others, 2015). Marine-terminating outlet glaciers have been identified as an important source of contemporary and near-future ice loss (IPCC, 2013; Nick and others, 2013) and currently account for between one-third and one-half of the total deficit from the Greenland ice sheet (van den Broeke and others, 2009; Shepherd and others, 2012; Enderlin and others, 2014).

Retreat rates were particularly high in south-east Greenland from 2000 until 2005 (e.g. Howat and others, 2008; Seale and others, 2011), although retreat, and the associated glacier acceleration, then slowed between 2005 and 2010 (e.g. Seale and others, 2011; Moon and others, 2012). Following changes in the south-east, glacier retreat began in the north-west from the mid-2000s (McFadden and others, 2011; Carr and others, 2013b; Murray, 2015), with almost $100 \%$ of glaciers in the region showing net retreat between 2000 and 2010 (Howat and Eddy, 2011). This was accompanied by substantial glacier acceleration (Moon and others, 2012) and ice loss (Khan and others, 2010). Recent work suggests that Greenland-wide outlet glacier recession has continued, with 35 glaciers retreating from a study population of 42 between 1999 and 2013 (Jensen and others, 2016). Elsewhere in the Arctic, accelerated glacier retreat occurred on Novaya Zemlya from $\sim 2000$ onwards, and retreat rates were an order of magnitude greater on marine-terminating outlets than those ending on land (Carr and others, 2014). Glacier retreat and thinning has also been observed across Svalbard since the early 20th century and has accelerated in recent years (e.g. Nuth and others, 2007; Blaszczyk and others, 2009; Moholdt and others, 2010; Nuth and others, 2010).

Key controls on Arctic outlet glacier dynamics are sea-ice concentrations, and air and ocean temperatures (e.g. Vieli and Nick, 2011; Carr and others, 2013a; Straneo and others, 2013). Sea-ice proximal to the glacier terminus is thought to influence the timing and nature of calving, by binding together icebergs to form a seasonal ice mélange (Sohn and others, 1998; Amundson and others, 2010). In winter, this mélange may suppress calving rates by up to a factor of six, through mechanical buttressing and/or iceberg pinning to the terminus (Joughin and others, 2008b; Amundson and others, 2010; Cassotto and others, 2015). Conversely, open water conditions in summer are thought to allow calving to recommence (Amundson and others, 
2010; Todd and Christoffersen, 2014; Moon and others, 2015). Consequently, low sea-ice concentrations near the calving front may extend the duration of seasonally high calving rates and thus promote interannual retreat, as suggested in north-west Greenland (Moon and others, 2015) and Jakobshavn Isbrae (Sohn and others, 1998; Joughin and others, 2008b; Amundson and others, 2010). Warmer air temperatures may promote glacier retreat through hydrofracture of crevasses at the lateral margins and/or close to the terminus (Vieli and Nick, 2011) and/or via sea-ice melt. Furthermore, increased melting, due to warmer air temperatures, may strengthen subglacial plumes, which strongly enhance submarine melt rates (Jenkins, 2011; Straneo and others, 2013). Finally, oceanic warming can control retreat rates through enhanced submarine melting, which leads to grounding line retreat and/or thinning of floating sections, and through undercutting of the calving front (e.g. Benn and others, 2007; Motyka and others, 2011; Vieli and Nick, 2011; Nick and others, 2012; Luckman and others, 2015). Increased sub-surface ocean temperatures may also affect the thickness and strength of the ice mélange, and sea ice, adjacent to glaciers. In addition to these external controls, factors specific to individual glaciers have the capacity to strongly modulate their response to forcing, particularly basal topography and fjord width variation (e.g. Jamieson and others, 2012; Moon and others, 2012; Enderlin and others, 2013; Carr and others, 2014; Carr and others, 2015; Bartholomaus and others, 2016). Much of our understanding of glacier response to these various forcing mechanisms comes from a limited number of marine-terminating glaciers. Consequently, there is major uncertainty regarding the relative importance of these controls over broader areas and across the Arctic. Specifically, it is unclear whether glacier retreat rates are similar across the Arctic, or whether there is clear regional clustering, and whether changes in atmospheric and/or oceanic forcing can explain these retreat patterns.

To address these uncertainties, we use remotely sensed data to investigate broad-scale patterns of glacier frontal position change for a large sample of study glaciers across the Atlantic sector of the Arctic, and relate this to climatic forcing (Fig. 1). Thus, we aim to provide an overview of recent changes in the Atlantic Arctic at the broadest spatial scale. Due to the extensive spatial coverage and a large number of glaciers involved, the analysis is at a decadal temporal resolution. Consequently, it allows us to identify if and where glaciers have undergone substantial net retreat and to assess the potential factors that might be driving these changes at decadal timescales, rather than providing a detailed analysis of the exact temporal pattern of retreat for each glacier and its relationship to climatic forcing. We aim to provide a broad-scale analysis, which can then be used as a guide for more detailed, high temporal resolution assessments in the areas exhibiting the highest retreat rates.

In this study, we assess glacier frontal position changes on 273 major marine-terminating glaciers (Fig. 1) in relation to: (i) climatic and oceanic forcing and (ii) fjord width variability, which we define as the variation in fjord width between the glacier's least and most extensive position during the study period. We use a combination of Landsat, ENVISAT and ERS satellite imagery to measure glacier retreat over two consecutive time steps: 1992-2000 and 2000-10. These intervals were selected on the basis of data availability and to encompass the period before and after the high retreat rates observed in the Arctic from the early 2000s onwards (e.g. Howat and others, 2008; Moon and Joughin, 2008; Carr and others, 2014; Jensen and others, 2016). We statistically evaluate changes in the mean rate of frontal position change and forcing between the two time steps and we assess the correlation between glacier retreat rates and (i) fjord geometry; and (ii) changes in air temperatures and sea-ice concentrations.

\section{METHODS}

\section{Glacier frontal position}

Following the approach employed in previous studies (e.g. Moon and Joughin, 2008; Carr and others, 2014), marineterminating outlet glacier frontal positions were obtained from a combination of Synthetic Aperture Radar (SAR) Image Mode Precision data (ERS-1, ERS-2 and Envisat), provided by the European Space Agency (ESA), and visible Landsat imagery, provided by the USGS Global Visualisation Viewer (http://glovis.usgs.gov/). We excluded glaciers that were previously identified as surge-type in the literature (e.g. Jiskoot and others, 2003; Grant and others, 2009; Sund and others, 2009; Joughin and others, 2010; Nuth and others, 2010) and/or in the World Glacier Inventory (http://nsidc.org/data/glacier_inventory/), and those $<1 \mathrm{~km}$ wide were excluded from the study. We processed the SAR imagery using the method detailed in Carr and others (2013b), specifically: (1) apply orbital state vectors; (2) calibrate radiometrically; (3) multl-look the imagery to reduce speckle; and (4) correct for the terrain. ERS images were coregistered with corresponding Envisat scenes, due to the higher geolocation accuracy of Envisat data.

Scenes were obtained for the years 1992, 2000 and 2010, and were acquired as close as possible to 31 July to minimise the impact of seasonal variations on interannual trends. For each year, we selected imagery as close to the same calendar date as possible, to minimise the impact of seasonal variability. The dates on which the frontal positions were obtained are shown in Supplementary Figure 1. Seasonal variations in frontal position vary markedly across the study region, both between regions and individual glaciers (Schild and Hamilton, 2013; Carr and others, 2014), and assessment of this seasonal variability is beyond the scope of this paper. As such, Supplementary Figure 1 provides context for the frontal position data and allows the reader to assess the potential impact of slightly different image dates on results. The spatial resolution of the imagery is $30 \mathrm{~m}$ for Landsat scenes and $37.5 \mathrm{~m}$ for the SAR data, after processing. After processing, we compared imagery from each year (1992, 2000 and 2010) for all scenes, to ensure that it was properly co-located. We did this by visually comparing features that should not move between images (e.g. rock ridges) and only images that were co-located at the imagery resolution were used. We measured changes in glacier frontal position using the reference box approach (e.g. Moon and Joughin, 2008; McFadden and others, 2011; Carr and others, $2013 \mathrm{~b}$ ) and used to calculate frontal position change between 1992-2000 and 2000-10. The glacier termini were digitised at a scale of 1:30,000. This provided a good compromise between the level of detail required to capture the terminus shape and the time required to digitise the terminus. The mean error in frontal position was calculated by repeatedly digitising sections of rock coastline for a 


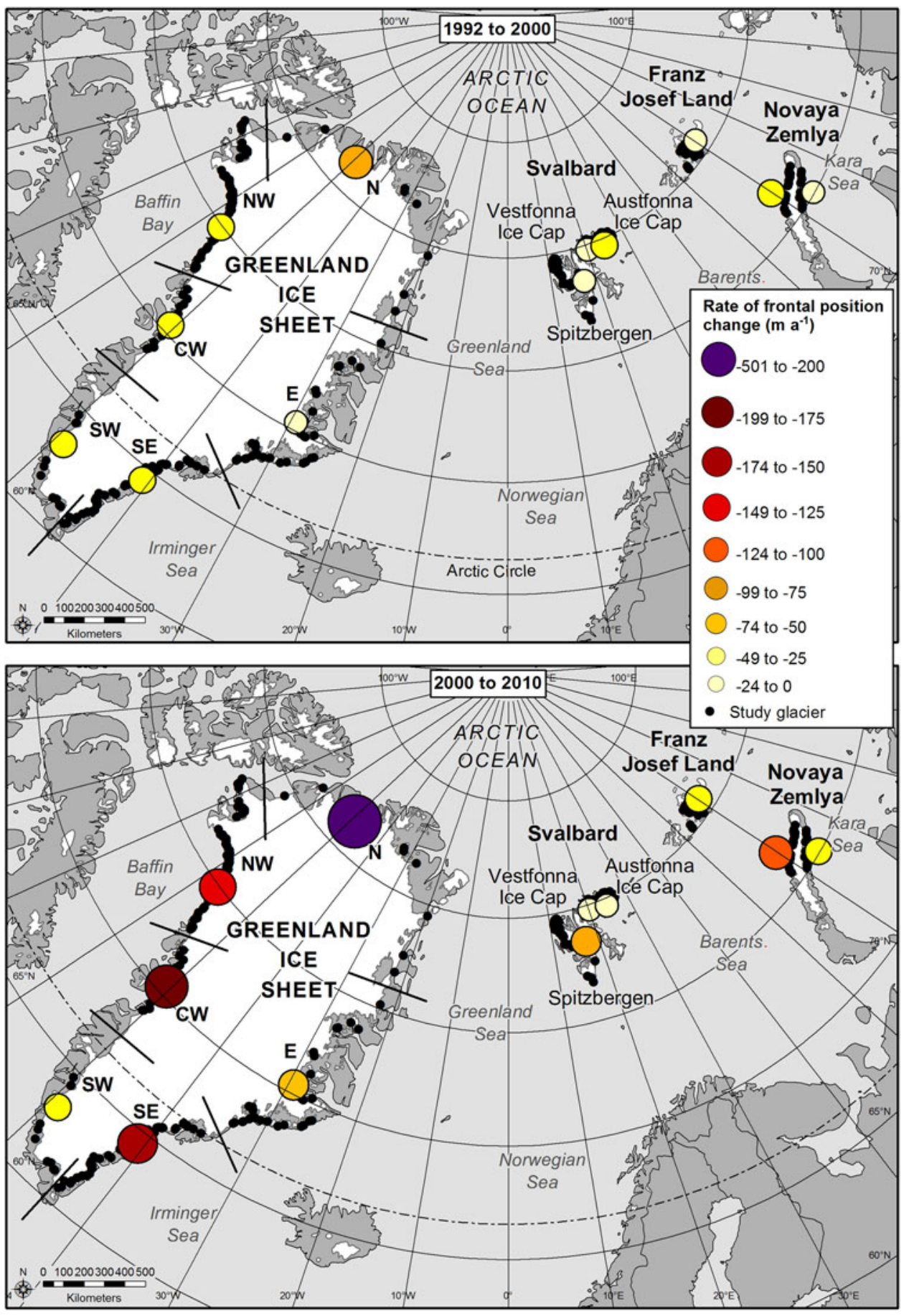

Fig. 1. Mean rate of a frontal position change for the periods $1992-2000$ and $2000-10$ by region. The colour and size of the circles show the magnitude of the glacier rate of frontal position change (yellow through red; larger circles = more rapid retreat). Black dots indicate study glaciers and black lines delineate Greenland ice sheet sub-regions, following (Moon and Joughin, 2008). All glaciers (both those advancing and retreating) were used to calculate the regional means.

sub-sample of ten ERS, ten ENVISAT and ten Landsat images, using the box method, which should show no discernible change between successive images (e.g. Moon and Joughin, 2008; Carr and others, 2013b; Carr and others, 2014). The total frontal position error was $27.1 \mathrm{~m}$ and results primarily from manual digitising errors: as discussed above, errors resulting from geolocation issues were minimalised by manually checking the co-location of scenes, but we are aware that it is easy to make small errors when digitising. This total frontal position error equates to an error in the rate of frontal position change (i.e. retreat or advance) of $\sim 3.4 \mathrm{~m} \mathrm{a}^{-1}$ for $1992-2000$ and 2.7 for $2000-10 \mathrm{~m} \mathrm{a}^{-1}$. For clarity, the rate of frontal position change has a negative sign when glaciers have retreated (e.g. $-600 \mathrm{~m} \mathrm{a}^{-1}$ indicates that the glacier retreated by $600 \mathrm{~m} \mathrm{a}^{-1}$ ) and a positive sign where glaciers have advanced.

To test whether regional patterns of retreat are simply a function of glacier size (i.e. that the magnitude of frontal position change is greater on larger glaciers, simply because of their size), we correlated the total rate of frontal position change (i.e. the rate of frontal position change between 1992 and 2010) against initial glacier width (in 1992) for 
all study glaciers. Initial glacier width was measured from the 1992 satellite imagery, approximately parallel to the glacier terminus and between the points at which the glacier terminus intersected with the fjord walls. Initial width was used instead of catchment area or glacier length, as accurate boundaries were not available for all glaciers, particularly the smaller outlets. First, a one-sample Kolmogorov-Smirnov test was used to determine whether the total rate of frontal position change data was normally distributed, which was not the case. Consequently, we used Spearman's rank correlation coefficient to determine correlation, as it is non-parametric and therefore does not assume a normal distribution. This test was used to correlate total rate of frontal position change (1992-2010) and initial glacier width (1992), and the resultant correlation coefficient was $-0.1434(P$-value $=0.02)$, which indicates a significant, but weak, negative correlation, i.e. wider glaciers are weakly associated with a lower total rate of frontal position change. This indicates that wider glaciers do not necessarily exhibit larger rates of the frontal position change.

\section{Air temperature data}

We acquired air temperature data from selected meteorological stations located across the Arctic (Carr and others, 2013a). Stations were chosen on the basis that data were available for the entire study period (1990-2010) and that data gaps were minimal. We obtained data from a variety of different sources (Supplementary Table 1). The temporal resolution of the available data ranged between 3-hourly and monthly. Data were filtered to account for missing values, using the following criteria: 3-hourly data were used only if (1) no more than two consecutive records were missing in a day; and (2) no more than three records in total were missing in a day. The resultant daily averages were then only used if values were available for 22 or more days per month and monthly values were used only if data were available for all summer (June-August) months (Cappelen, 2011). For each station, we calculated an annual time series of mean summer values (June-August), as warming during these months is likely to have the greatest direct impact on glacier retreat. Furthermore, this excludes winter values, as winter warming could promote positive mass balance and advance (e.g. through enhanced precipitation associated with a warmer atmosphere). Summer air temperature values (June-August) were averaged over the time periods 1990-99 and 2000-10 and used to identify the magnitude of change between the two time steps.

\section{Sea-ice data}

We acquired sea-ice data from the National/Naval Ice Centre Charts (http://www.natice.noaa.gov/). The charts are compiled from a wide range of remotely sensed and directly measured data sources and have a spatial resolution of up to $50 \mathrm{~m}$. This dataset was selected as it has a comparatively high resolution and incorporates different data sources, but also covers the entire study region. Thus, it can provide information on sea-ice conditions within glacial fjords, but may not be representative of conditions directly at the glacier front. It represents the best-available dataset that covers the entire study region. Data are available at a bi-weekly temporal resolution, from 1995 onwards. Sea-ice concentrations were sampled at the terminus of each study glacier, from a polygon spanning the fjord width, within $50 \mathrm{~m}$ of the glacier terminus. These data were used to calculate mean values for the following parameters for the periods 199599 and 2000-10: mean seasonal sea-ice concentrations for January-March, April-June, July-September, OctoberDecember, mean annual sea-ice concentration and number of ice-free months. Here, we define 'ice-free' as a sea concentration of $<10 \%$, because small amounts of sea ice may be present within the fjord, but would not have any impact on glacier retreat and/or the calving process. A higher threshold was not selected, as the sea-ice concentrations of 20 or $30 \%$ could impact glacier behaviour, e.g. if the sea ice forms at the glacier front or impedes the movement of icebergs from the fjord. We also calculated time series of mean annual sea-ice concentration, which were used to statistically evaluate change between the two study periods.

\section{Sub-surface ocean temperature data}

Sub-surface ocean temperature data were obtained from the TOPAZ4 Arctic Ocean Reanalysis, supplied by Copernicus Marine Environment Monitoring Service (http://marine. copernicus.eu/web/69-interactive-catalogue.php?option= com_csw\&view=details\&product_id=ARCTIC_REANALYSIS_ PHYS_002_003). The product assembles oceanic information from a combination of satellite and in situ measurements and assimilates them using the model HYCOM. The data have a spatial resolution of $1 / 4^{\circ}$ and we use the monthly product, which is available from 1991 to 2013. The RMSE for ocean temperatures is between 0.32 and $0.95^{\circ} \mathrm{C}$ at depths of 0 , $100,300,800$ and $2000 \mathrm{~m}$. Full details of the data errors and validation process for the data are available here: http:// marine.copernicus.eu/documents/QUID/CMEMS-ARC-QUID002-003.pdf. We use data from depths of 5 and $200 \mathrm{~m}$, in order to capture changes within the different water masses we expect to find within an Arctic outlet glacier fjord (e.g. Rignot and others, 2010; Johnson and others, 2011; Straneo and others, 2011; Politova and others, 2012; Straneo and others, 2012; Straneo and others, 2013). Specifically, we use data at $5 \mathrm{~m}$ depth to include the comparatively fresh, cool surface layer. Based on the limited number of direct measurements (e.g. Holland and others, 2008; Politova and others, 2012; Straneo and others, 2012), data from $200 \mathrm{~m}$ depth should include warmer, sub-surface waters that are likely to reach the glacier fronts (i.e. Atlantic Water: AW), and is also sufficiently shallow to assess sub-surface changes in areas with a comparatively shallow continental shelf (e.g. immediately offshore of the Barents Sea coast of Novaya Zemlya). We acknowledge that AW depth varies seasonally (e.g. Straneo and others, 2011), but use a depth of $200 \mathrm{~m}$ as the best compromise between being shallow enough to include areas like Novaya Zemlya and Svalbard, but being deep enough to capture the AW in areas with deeper troughs, such as Greenland. Where deeper data (e.g. $400 \mathrm{~m}$ depth) are available, similar temporal trends are evident. It should be noted that the data do not represent conditions at the glacier termini, but instead are used as a broad-scale indicator of changes on the continental shelf, because oceanographic data are not available for the vast majority of Arctic outlet glacier fjords. For each depth (5 and $200 \mathrm{~m}$ ), we calculated mean values for the periods 1991-99 and 2000-10 for each grid square in the study region, and used these data to determine the change in ocean temperature between the two time intervals. 


\section{Fjord width variability}

Following Carr and others (2014), we measured fjord width variability by digitising both fjord walls at sea level from the most recent satellite imagery, at a scale of $1 ; 30000$. This was done between the least and most extensive frontal positions occupied by each study glacier between 1992 and 2010. The length of each fjord wall was then divided by the straight-line distance between its start and end points, and a mean dimensionless value for fjord width variability was obtained for each glacier from these values. A value of 1 for fjord width variability, therefore, indicates that the fjord walls are completely straight, while higher values indicate greater fjord width variation. Fjord width variability was calculated only for glaciers with continuous fjord walls and glaciers retreating across stretches of open water (e.g. between two islands) were not included. Only glaciers that underwent net retreat, not net advance, were included in the analysis, which corresponded to 212 out of 273 study glaciers.

\section{Statistical analysis}

Following (Miles and others, 2013), we used the Wilcoxon test to determine whether there was a statistically significant difference in rates of frontal position change between the two time intervals in our study period (1992-2000 and 2000-10). This test was chosen because it is non-parametric and rates of glacier frontal position change are not normally distributed. We also used the Wilcoxon test to evaluate significant differences between the two time periods for air temperatures (1990-99 and 2000-10), sea-ice (1995-99 and 2000-10) and ocean temperatures determined from reanalysis data (1991-99 and 2000-10), as they are not normally distributed. The $P$-value indicates the likelihood of obtaining a difference that is as large, or larger, than the difference observed, if the null hypothesis is true (i.e. there is no difference between the two time periods). Following convention, a $P$-value of $\leq 0.05$ indicates a 'significant' difference (95\% confidence), a $P$-value of $\leq 0.01$ indicates a 'highly -significant' difference (99\% confidence) and a $P$-value of $\leq 0.001$ indicates a 'very highly significant' difference ( $>99 \%$ confidence).

We also tested the statistical relationship between the 2000-10 rate of a frontal position change for each glacier and the magnitude of change in summer air temperatures and sea-ice concentrations between 1990-99 and 2000-10. Sub-surface ocean temperatures were not included in this analysis, as they are produced via reanalysis and are not necessarily representative of conditions at the front. Consequently, they are used to identify broad-scale patterns of change only. For summer (JJA) air temperatures, we selected the meteorological station closest to each glacier and removed any stations that were more than $200 \mathrm{~km}$ away or were clearly geographically separated from the station (e.g. by a major mountain ridge), to avoid erroneous correlations. To ensure that this threshold distance did not affect results, we also carried out the test using distances of 250 and $150 \mathrm{~km}$, and found no difference in the significance of the relationship (see results). Lower threshold distances (e.g. $50 \mathrm{~km}$ ) were not used, as so few glaciers were this close to the meteorological stations, meaning that our results would not be representative and that one or two glaciers could have substantially affected our results.

For sea ice, we correlated 2000-10 rate of frontal position change at each glacier with the change in (i) mean seasonal values of sea-ice concentration (January-March, April-June, July-September and October-December); (ii) mean annual concentration and (iii) the number of ice-free months. For both air temperatures and sea ice, we used Spearman's rank correlation coefficient. This was selected in preference to (multiple) linear regression or Pearson's correlation coefficient, as it reduces the impact of outliers and is non-parametric. The data on the rate of frontal position change are not normally distributed and have outliers, which can strongly affect the correlation coefficients in linear regression and Pearson's correlation coefficient. We did not remove the outliers, as they are 'real' data, as opposed to errors, and so their removal would also bias the correlation results. For Spearman's rank correlation coefficient, a correlation coefficient $(\rho$; rho) of +1 indicates a perfect positive correlation, a value of -1 a perfectly negative correlation and 0 shows no correlation. The significance of the relationship is shown by the $P$-value and a $P$-value of $\leq 0.05$ (95\% confidence) is taken as significant, following convention. Spearman's rank correlation coefficient was also used to assess the relationship between fjord width variability and total (1992-2010) retreat rate.

\section{RESULTS}

\section{Glacier frontal position change}

Overall, our results demonstrated that there was a widespread retreat of marine-terminating outlet glaciers between 1992 and 2010, and there was a marked increase in the rate of retreat from $-30.5 \mathrm{~m} \mathrm{a}^{-1}$ in 1992-2000 (median $=-17.2$ $\mathrm{m} \mathrm{a}^{-1}$ ) to $-105.8 \mathrm{~m} \mathrm{a}^{-1}$ for 2000-10 (median $=-374.6$ $\mathrm{m} \mathrm{a}^{-1}$ ) (Table 1; Fig. 1). Between 1992 and 2000, 74\% of the study glaciers underwent net retreat and every region contained retreating glaciers (Table 1). Each region also had glaciers that advanced ( $18 \%$ of all glaciers) or showed no discernible change $(8 \%$ of all glaciers; i.e. change less than the frontal position error), with notable clusters occurring in southern and eastern Greenland, northern Svalbard and Franz Josef Land (FJL; Table 1, Fig. 2). In contrast, 97\% of glaciers retreated between 2000 and 2010, with only $1.8 \%$ showing no discernible change and $1.5 \%$ advancing (Table 1, Fig. 2). Glaciers showing no discernible change or those that advanced were predominantly located in southern Greenland and north-eastern Svalbard and advances were generally small ( $<10 \mathrm{~m} \mathrm{a}^{-1}$; Table 1, Fig. 2$)$. When taken as an entire population, the rates of glacier frontal position change in 2000-10 were significantly greater $(P<0.001)$ than those in 1990-2000 (Table 1). When split according to region, significant differences $(P<0.001)$ between the two time periods exist for the majority of regions (NW, SW, E and SE Greenland, Novaya Zemlya Barents Sea, FJL and Spitzbergen) and significant differences $(\leq 0.05)$ are apparent in northern and central-west Greenland (Table 1). There was no significant difference between the two time intervals in south-west Greenland, the Kara Sea coast of Novaya Zemlya, Austfonna or Vestfonna (Table 1).

The highest mean regional retreat rates between 2000 and 2010 occurred in northern Greenland (retreat rates exceed$600 \mathrm{~m} \mathrm{a}^{-1}$ ), which represented an eightfold increase compared with 1992-2000 (Table 1). Within this mean value, three glaciers had particularly high retreat rates (mean retreat rates exceed $-1000 \mathrm{~m} \mathrm{a}^{-1}$ for 2000-10) and the other six also showed high rates of between -68.0 and 
Table 1. Overview of glacier frontal position change statistics by region for the periods 1992-2000 and 2000-10

\begin{tabular}{|c|c|c|c|c|c|c|c|c|c|c|c|c|c|c|c|c|}
\hline \multicolumn{9}{|c|}{ 1992-2000 } & \multicolumn{7}{|c|}{ 2000-10 } & \multirow{3}{*}{$\begin{array}{l}\text { Wilcoxon test } \\
P \text {-value }\end{array}$} \\
\hline \multirow[t]{2}{*}{ Region } & \multirow[t]{2}{*}{$\begin{array}{l}\text { No. of } \\
\text { glaciers }\end{array}$} & \multirow[t]{2}{*}{$\begin{array}{l}\text { Retreat } \\
\%\end{array}$} & \multirow[t]{2}{*}{$\begin{array}{l}\text { No change } \\
\%\end{array}$} & \multirow[t]{2}{*}{$\begin{array}{l}\text { Advance } \\
\%\end{array}$} & \multicolumn{4}{|c|}{$\begin{array}{l}\text { Mean rate of frontal position change } \\
\mathrm{m} \mathrm{a}^{-1}\end{array}$} & \multirow[t]{2}{*}{$\begin{array}{l}\text { Retreat } \\
\%\end{array}$} & \multirow[t]{2}{*}{$\begin{array}{l}\text { No change } \\
\%\end{array}$} & \multirow[t]{2}{*}{$\begin{array}{l}\text { Advance } \\
\%\end{array}$} & \multicolumn{4}{|c|}{$\begin{array}{l}\text { Mean rate of frontal position change } \\
\mathrm{m} \mathrm{a}^{-1}\end{array}$} & \\
\hline & & & & & Mean & S.D. & Median & I.Q. range & & & & Mean & S.D. & Median & I.Q. range & \\
\hline N GrlS & 9 & 87.5 & 0 & 12.5 & -77.3 & 227.91 & -86.9 & 114.1 & 100.0 & 0 & 0 & -624.1 & 638.48 & -197.6 & 1137.0 & 0.050 \\
\hline NW GrlS & 55 & 88.7 & 5.7 & 5.7 & -37.5 & 54.46 & -19.1 & 37.0 & 100.0 & 0 & 0 & -116.6 & 180.27 & -48.3 & 78.8 & $<0.001$ \\
\hline CW Grls & 19 & 73.7 & 10.5 & 15.8 & -38.6 & 77.89 & -16.7 & 32.6 & 94.7 & 0 & 5.3 & -168.0 & 263.64 & -66.9 & 209.4 & 0.015 \\
\hline SW GrlS & 10 & 80.0 & 0 & 20.0 & -34.9 & 45.73 & -14.6 & 62.2 & 70.0 & 20.0 & 10.0 & -48.1 & 62.23 & -11.1 & 86.6 & 0.791 \\
\hline E GrlS & 33 & 51.5 & 36.4 & 12.1 & -20.49 & 52.43 & -3.4 & 30.1 & 97.0 & 0 & 3.0 & -72.8 & 110.11 & -29.7 & 67.8 & $<0.001$ \\
\hline SE GrlS & 43 & 69.8 & 16.3 & 14.0 & -42.7 & 56.61 & -33.9 & 58.2 & 95.3 & 2.3 & 2.3 & -135.9 & 170.2 & -66.2 & 148.2 & $<0.001$ \\
\hline NVZ (B) & 18 & 82.4 & 0 & 17.6 & -27.1 & 25.41 & -26.0 & 44.7 & 100.0 & 0 & 0 & -77.4 & 48.55 & -79.0 & 63.1 & $<0.001$ \\
\hline NVZ (K) & 10 & 80.0 & 0 & 20.0 & -20.3 & 18.78 & 15.9 & 25.8 & 100.0 & 0 & 0 & -44.2 & 28.27 & -46.3 & 35.4 & 0.064 \\
\hline FJL & 28 & 67.9 & 10.7 & 21.4 & -17.1 & 28.35 & -14.1 & 24.3 & 100.0 & 0 & 0 & -38.6 & 21.25 & -33.1 & 21.0 & $<0.001$ \\
\hline SPITZ & 29 & 72.4 & 10.3 & 17.2 & -18.9 & 31.23 & -11.6 & 28.6 & 100.0 & 0 & 0 & -58.33 & 31.9 & -55.2 & 43.1 & $<0.001$ \\
\hline $\mathrm{AF}$ & 10 & 80.0 & 10.0 & 10.0 & -28.8 & 21.2 & -31.4 & 23.6 & 90.0 & 10.0 & 0 & -23.1 & 21.2 & -26.8 & 23.3 & 0.521 \\
\hline VF & 8 & 62.5 & 0 & 37.5 & -1.6 & 15.47 & -5.8 & 13.0 & 87.5 & 0 & 12.5 & -14.8 & 28.85 & -20.6 & 37.0 & 0.065 \\
\hline ALL & 273 & 74.0 & 8.2 & 17.8 & -30.5 & 64.28 & 17.2 & 36.6 & 96.7 & 1.8 & 1.5 & -105.8 & 205.68 & 374.6 & 70.6 & $<0.001$ \\
\hline
\end{tabular}

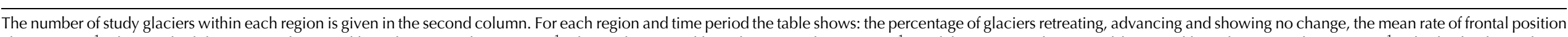

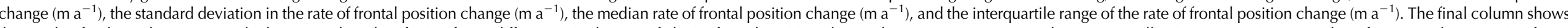

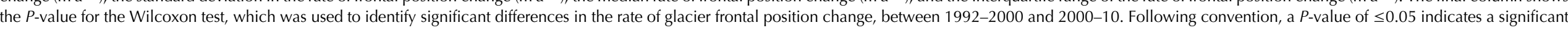
difference and these values are in bold. 

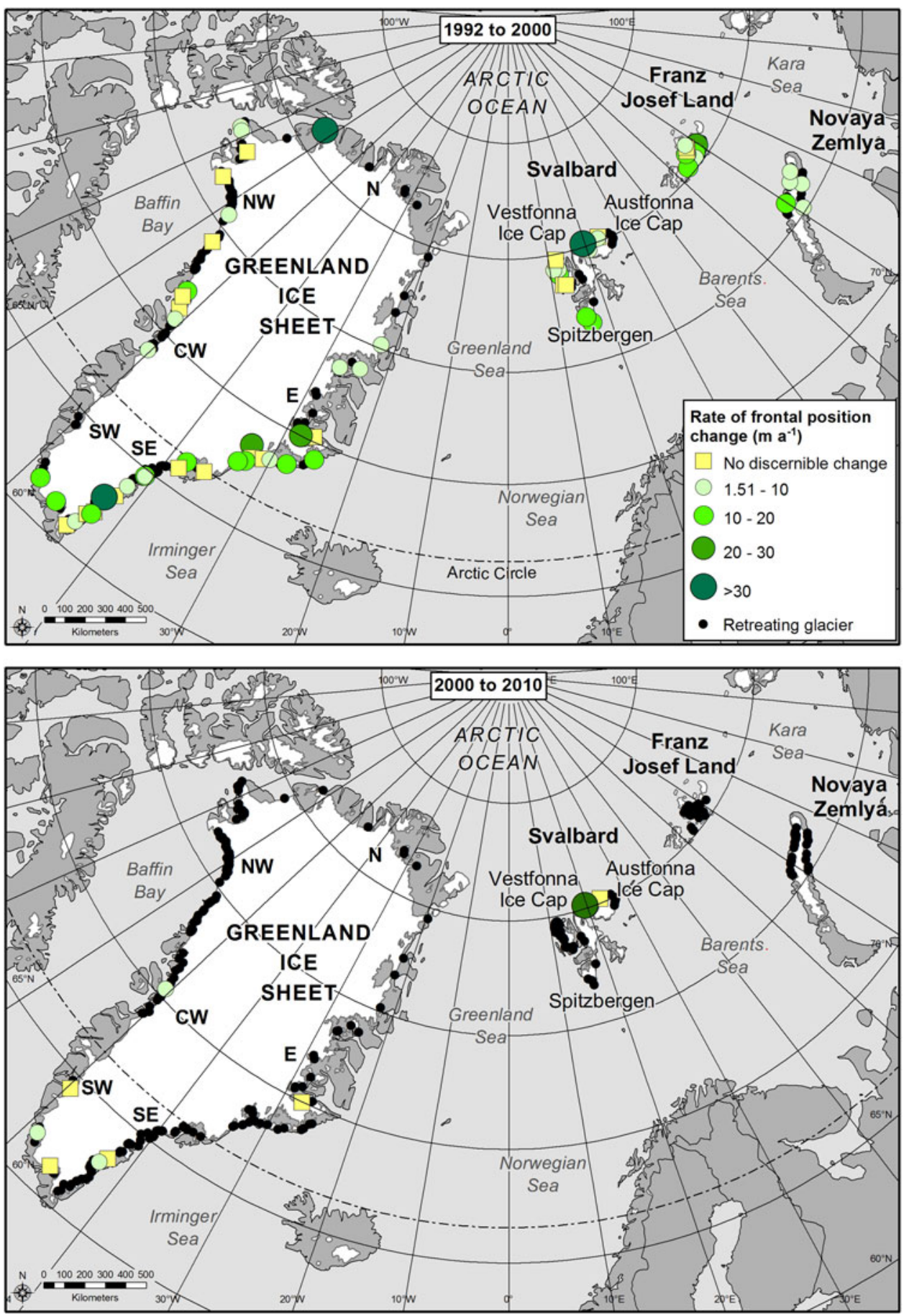

Fig. 2. The location of individual marine-terminating outlet glaciers showing advance or no discernible change for the periods 1992-2000 and 2000-10. Frontal advance is symbolised by colour and size, with larger symbols indicating more rapid advance. Glaciers showing no discernible change are indicated by a square. Retreating glaciers are shown by black dots. The figure focuses only on glaciers undergoing net advance or no discernible change, in order to highlight the location and the number of these glaciers, and because also including glaciers that retreated would substantially reduce its clarity. Maps of frontal position change for all glaciers, for each sub-region, are provided in Supplementary Figures 3-6.

$-643.8 \mathrm{~m} \mathrm{a}^{-1}$ (Supplementary Fig. 2). None of the glacier retreat rates in northern Greenland was outliers, where an outlier is defined as a data point more than 1.5 times the interquartile range above the upper quartile or below the lower quartile. After northern Greenland, retreat rates were highest in central-west, south-east and north-west Greenland, where values were more than triple their 1992-2000 values and showed a statistically significant increase between the two time periods (Fig. 1 \& Table 1). Two outliers were identified in south-east and one in central-west Greenland, but even after removing these points, retreat rates remained substantially higher than in other regions $\left(-105.5 \mathrm{~m} \mathrm{a}^{-1}\right.$ for the south-east and $-108.7 \mathrm{~m} \mathrm{a}^{-1}$ for the central-west). In contrast, removing the nine outlying values (of a total of 55) in north-west Greenland reduced the mean retreat rates considerably $\left(-51.3 \mathrm{~m} \mathrm{a}^{-1}\right.$ c.f. $-115.8 \mathrm{~m} \mathrm{a}^{-1}$ ) (Supplementary Fig. 2). This indicates that these nine glaciers strongly influence regional rates of frontal position change, but they are retained within the regional assessment, as they remain part of the region and excluding them would falsely skew the 
data. Retreat rates were notably smaller in south-west and east Greenland, than for the rest of the ice sheet. Elsewhere, glacier recession was higher on the western (Barents Sea) coast of Novaya Zemlya than in eastern Greenland and it exhibited the highest retreat rates outside of the ice sheet, highlighting it as an emerging area of glacier change (Fig. 1 \& Table 1). The lowest retreat rates occurred on Austfonna and Vestfonna, with Austfonna being the only region to exhibit a deceleration in retreat between the two time periods (Fig. 1; Table 1).

\section{Fjord width variability}

Although regional-scale retreat patterns were apparent, there was large variability between individual glaciers and within regions (Fig. 1; Supplementary Information Figs 3-6), indicating that local factors strongly modulated glacier response to forcing. Fjord topography has previously been highlighted as a potential control in more localised studies (e.g. Warren and Glasser, 1992; Enderlin and others, 2013; Carr and others, 2014; Porter and others, 2014) and, in order to investigate this, we assessed the relationship between glacier retreat and variations in fjord width along its retreat path (Table 2). Results show a highly significant statistical relationship between along-fjord width variability (the ratio of shoreline length between the maximum and minimum terminus positions to the straight-line distance) and total retreat rate (1992-2010) (Table 2). For the entire population, there was a strong and highly significant negative correlation $\left(\rho=-0.570 P\right.$-value $\left.=1.20 \times 10^{-19}\right)$, which suggests that glaciers with greater (i.e. more positive) along-fjord width variability have higher (i.e. more negative) total retreat rates (Table 2). When the data are split into individual regions, this statistically significant relationship is widespread and persists along the west Greenland coast (NW, CW and SW), in East Greenland, Novaya Zemlya, Spitzbergen and FJL, which together accounts for 197 glaciers out of the total of 216 glaciers with continuous fjord walls (Table 2). No significant relationship was apparent between

Table 2. Correlation results for along-fjord width variability versus total mean retreat rate (1992-2010)

\begin{tabular}{lrrr}
\hline Regiona & $n$ & $\rho$ (rho) & $P$-value \\
\hline N GrlS & 8 & -0.071 & 0.906 \\
NW GrIS & 42 & $-\mathbf{0 . 6 6 3}$ & $<\mathbf{0 . 0 0 1}$ \\
CW GrIS & 17 & $-\mathbf{0 . 6 2 0}$ & $\mathbf{0 . 0 0 9}$ \\
SW GrlS & 8 & $-\mathbf{0 . 9 0 5}$ & $\mathbf{0 . 0 0 5}$ \\
E GrIS & 31 & $-\mathbf{0 . 6 6 3}$ & $<\mathbf{0 . 0 0 1}$ \\
SE GrlS & 35 & $-\mathbf{0 . 5 0 6}$ & $\mathbf{0 . 0 0 2}$ \\
Spitzbergen & 23 & $-\mathbf{0 . 7 5 2}$ & $<\mathbf{0 . 0 0 1}$ \\
Austfonna & 5 & -0.051 & 1 \\
Vestfonna & 6 & 0.371 & 0.497 \\
Novaya Zemlya & 20 & $-\mathbf{0 . 7 4 6}$ & $<\mathbf{0 . 0 0 1}$ \\
FJL & 21 & $-\mathbf{0 . 5 3 8}$ & $\mathbf{0 . 0 1 6}$ \\
All & 212 & $-\mathbf{0 . 5 7 0}$ & $<\mathbf{0 . 0 0 1}$ \\
& & &
\end{tabular}

Spearman's rank correlation coefficient was used to assess correlation. A value of 1 for $\rho$ (rho) indicates a perfect positive correlation, 0 indicates no correlation and a value of -1 indicates a perfect negative correlation. The $P$-value indicates the significance of the correlation, with a value of $\leq 0.05$ indicating a significant result and these values are highlighted in bold. Glaciers are divided according to region and statistical analysis was performed on glaciers with continuous fjord walls and those which were retreating, which accounts for $78 \%$ of the study glaciers. ' $n$ ' indicates the number of glaciers within each sample. fjord width variability and total retreat rate in northern Greenland, Austfonna or Vestfonna (Table 2).

\section{CLIMATIC AND OCEANIC FORCING}

\section{Air temperatures}

Mean summer (JJA) air temperatures at all but one of the meteorological stations were warmer in 2000-10 than 1990-99 (Fig. 3). By far the strongest warming occurred in north- and central-west Greenland, where summer air temperatures warmed by over $2{ }^{\circ} \mathrm{C}$ at Nuussuaq $\left(2.28^{\circ} \mathrm{C}\right)$ and Kitsissorsuit $\left(2.42^{\circ} \mathrm{C}\right)$ and warming was significant $(P=<0.001)$ (Table 3). Substantial temperature increases also occurred on the northern coast of Russia, at Dikson $\left(1.41^{\circ} \mathrm{C}\right)$ and Kolguev Severnyj $\left(1.24^{\circ} \mathrm{C}\right)$ (Fig. 3). Along much of the south-west Greenland margin, summer temperatures rose by $1.2-1.4^{\circ} \mathrm{C}$, which represented a significant increase between 1990-99 and 2000-10 (Table 3), although warming was lower close to Cape Farvel (Fig. 3). Conversely, warming was greatest in the southern portion of south-east Greenland and reduced to just over $1{ }^{\circ} \mathrm{C}$ further north at Ikermit $\left(1.07^{\circ} \mathrm{C}\right)$ and Tasiilaq $\left(1.05^{\circ} \mathrm{C}\right)$. Summer warming was comparatively limited in eastern and northern Greenland, reaching a maximum of $0.52^{\circ} \mathrm{C}$ at Danmarkshavn (Fig. 3).

To further assess the relationship between retreat and summer air temperatures, we correlated the mean rate of frontal position change (2000-10) with the change in summer (June-August) air temperature between 1990-99 and 2000-10 (Table 4). We used a threshold of $200 \mathrm{~km}$ distance between each glacier and its nearest meteorological station, to avoid erroneous correlations and found no significant relationship $(\rho=-0.07 ; P$-value $=0.41)($ Table 4$)$. No glacier had more than one meteorological station within $200 \mathrm{~km}$. The significance of this relationship did not change with distance thresholds of $150 \mathrm{~km}(\rho=0.02 ; P$-value $=$ $0.85)$ and $250 \mathrm{~km}(\rho=-0.07 ; P$-value $=0.37)($ Table 4$)$.

\section{Sea ice}

The largest changes in mean annual sea-ice concentrations between 1995-99 and 2000-10 occurred on the centraland north-west Greenland coast, on the west coast of Spitzbergen and Novaya Zemlya, and FJL (Fig. 4, Table 3). In these regions, sea-ice loss close to the glacier termini was of the order of $10 \%$ or more (Fig. 4) and represented a significant reduction compared with 1995-99 (Table 3). Decline in mean annual sea-ice concentrations was more limited in magnitude on the eastern (Kara Sea) coast of Novaya Zemlya (2.2-6.2\% reduction), in eastern Greenland to the north of the Fram Strait $(0.9-5.1 \%$ reduction), and surrounding Austfonna and Vestfonna ice caps $(-6.4 \%$ to $+5.4 \%$ ) (Fig. 4). In south-east Greenland, the reduction in the mean annual sea ice between 1995-99 and 2000-10 was high close to Cape Farvel, but was much less to the north (Fig. 4) and not significant overall (Table 3). This pattern of sea-ice change in south-east Greenland corresponds to the spatial pattern of atmospheric warming (Fig. 4).

Focusing on mean seasonal changes between 1995-99 and 2000-10, strong reductions in mean sea-ice concentrations occurred during Autumn (October-December) across the majority of the study area: central-west, north-west and east Greenland, western Spitzbergen and FJL (Fig. 6). In the summer months (July-September), large changes in sea-ice 


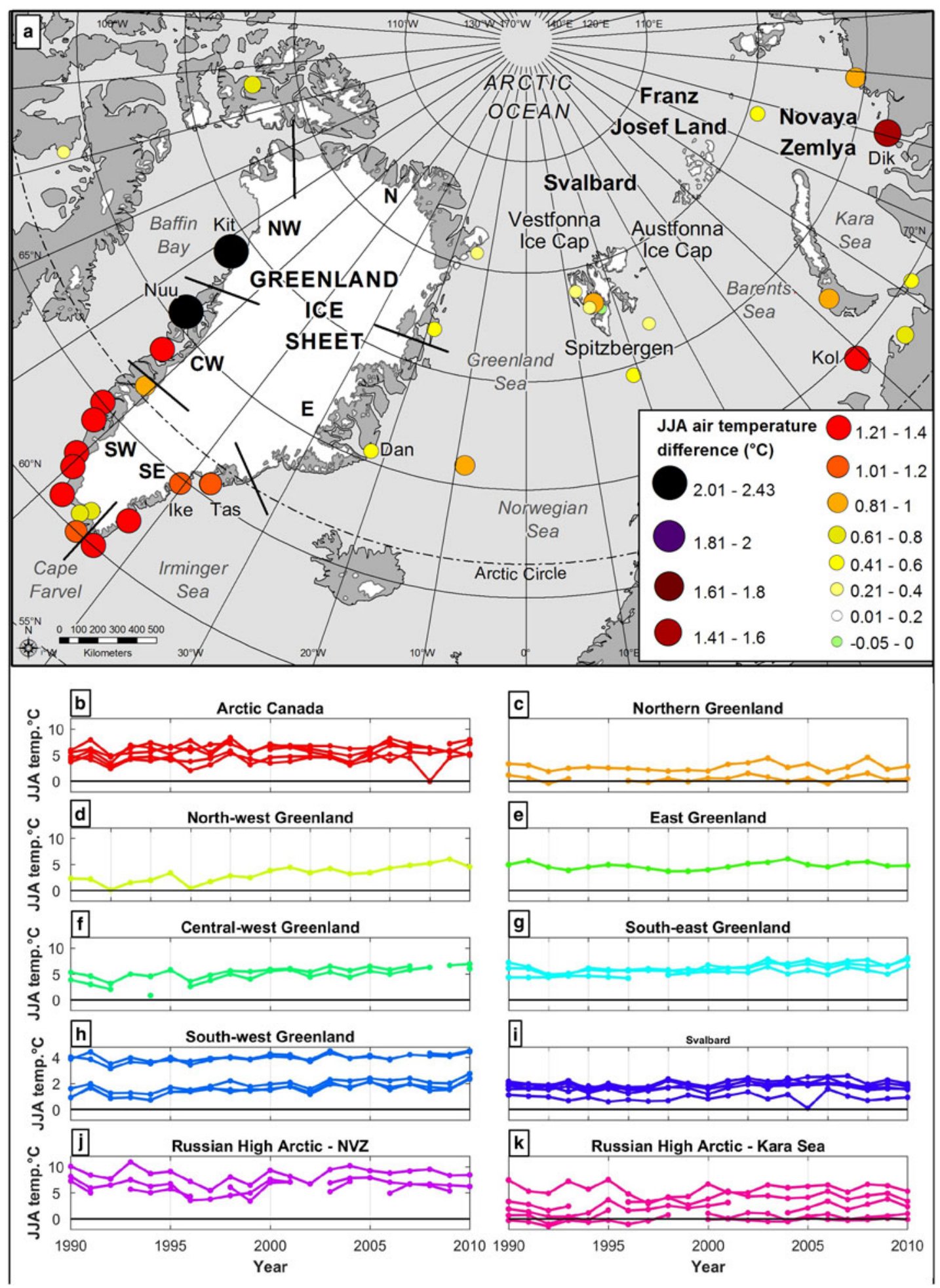

Fig. 3. (a) Difference in mean summer (June-August) air temperatures for the period 2000-10, relative to 1990-2010, for selected Arctic meteorological stations. Symbol size and colour show the magnitude of the change in ${ }^{\circ} \mathrm{C}$. Meteorological stations discussed in the text are identified: Dan, Danmarkshavn; Dik, Dikson; Ike, Ikermit; Kit, Kitsissorsuit; Kol, Kolguev Severnyj; Nuussuaq; Tas, Tasiilaq. (b—-k) Time series of mean summer air temperatures for selected meteorological stations. Time series are grouped according to the location of the meteorological station and stations were selected on the basis of continuity and length of the data record.

concentrations were confined to northern north-west Greenland $(P<0.001)$ and FJL $(P<0.002)$ (Fig. 6; Table 3). Significant sea-ice reductions occurred during winter (January-March) on FJL, Spitzbergen, the Barents Sea coast of Novaya Zemlya, and north- and central-west Greenland (Fig. 7, Table 3). Results show a significant reduction in winter sea-ice concentrations in northern Greenland (Table 3), but this was due to a reduction in concentrations from 100 to $92.5 \%$ at all locations in 2007, which reduced the $2000-10$ mean to $99.8 \%$, and is unlikely to affect ice dynamics. In spring (April-June), changes in mean seasonal sea-ice concentrations were less widespread than for autumn, and were significant on FJL, the Barents Sea coast of Novaya Zemlya, and north-west and east Greenland, with the magnitude of change reducing with distance north in north-west Greenland (Fig. 7, Table 3). 
Table 3. Wilcoxon test results for significant differences between summer (June-August) air temperature, ocean temperature and sea ice for the 1990s and 2000s by region: 1990-99 and 2000-10 for air temperatures, 1991-99 and 2000-10 for ocean temperatures and 1995-99 and 2000-10 for sea ice

\begin{tabular}{|c|c|c|c|c|c|c|c|c|c|}
\hline \multirow[t]{3}{*}{ Region } & \multicolumn{9}{|c|}{ Wilcoxon test $P$-value } \\
\hline & \multirow[t]{2}{*}{$\begin{array}{l}\text { JJA Air temperature } \\
{ }^{\circ} \mathrm{C}\end{array}$} & \multicolumn{2}{|c|}{ Ocean temperature } & \multicolumn{5}{|c|}{$\begin{array}{l}\text { Sea-ice concentration } \\
\%\end{array}$} & \multirow{2}{*}{$\begin{array}{l}\text { Sea ice } \\
\text { Ice-free months }\end{array}$} \\
\hline & & 5 m depth & $200 \mathrm{~m}$ depth & JFM & AMJ & JAS & OND & Mean annual & \\
\hline N GrlS & 0.418 & 0.182 & 0.013 & $<0.001$ & 0.648 & 0.287 & 0.371 & 0.190 & 0.188 \\
\hline NW GrIS & $<0.001$ & $<0.001$ & 0.595 & $<0.001$ & 0.032 & $<0.001$ & $<0.001$ & $<0.001$ & $<0.001$ \\
\hline CW Grls & $<0.001$ & 0.014 & 0.305 & 0.021 & 0.264 & 0.066 & 0.007 & 0.018 & 0.007 \\
\hline SW GrIS & 0.028 & 1 & 0.025 & 0.117 & 0.554 & 0.665 & 0.080 & 0.288 & 0.686 \\
\hline E GrlS & 0.053 & 0.102 & 0.036 & 0.235 & 0.016 & 0.830 & $<0.001$ & $<0.001$ & $<0.001$ \\
\hline SE GrlS & $<0.001$ & 0.288 & 0.197 & 0.304 & 0.485 & 0.028 & 0.002 & 0.816 & 0.740 \\
\hline NVZ (B) & 0.195 & 0.002 & 0.002 & $<0.001$ & 0.027 & 0.054 & 0.079 & $<0.001$ & $<0.001$ \\
\hline NVZ (K) & No data & 0.048 & 0.494 & 0.373 & 0.245 & 0.811 & 0.421 & 0.024 & $<0.001$ \\
\hline FJL & No data & $<0.001$ & 1 & $<0.001$ & $<0.001$ & $<0.001$ & $<0.001$ & $<0.001$ & $<0.001$ \\
\hline Spitzbergen & 0.321 & 0.171 & 0.025 & 0.010 & 0.352 & 0.840 & $<0.001$ & 0.006 & 0.289 \\
\hline $\mathrm{AF}$ & No data & 0.790 & 0.790 & 0.100 & 1 & 0.307 & 0.017 & 0.427 & 0.360 \\
\hline VF & No data & 0.003 & 0.006 & 0.122 & 0.365 & 0.365 & 0.018 & 0.902 & 0.048 \\
\hline
\end{tabular}

Results are given by region, not for individual glaciers. The $P$-value indicates the likelihood of a given outcome occurring by chance, if the null hypothesis is true. Following convention, a $P$-value of $\leq 0.05$ indicates a significant difference (bold).

Previous studies suggest that the length of the ice-free season and the timing of sea-ice formation and disintegration may strongly influence calving rates (e.g. Joughin and others, 2008b; Carr and others, 2014; Todd and Christoffersen, 2014; Moon and others, 2015). We therefore, assessed changes in the mean number of ice-free months and mean seasonal sea-ice concentrations between 1995-99 and 2000-10 (Figs. 5-7). Overall, the change in the mean number of ice-free months between 1995-99 and 2000-10 follows a similar spatial pattern as changes in mean annual sea-ice concentration (Figs. 4 \& 5) and significant reductions occurred in the majority of regions (Table 3 ). In the north-

Table 4. Spearman's rank correlation coefficient test results for the relationship between the 2000 and 2010 retreat rate for each individual glacier and the magnitude of change in summer air temperatures and sea-ice concentrations between 1990-99 and 2000-10

\begin{tabular}{lrc}
\hline Variable & \multicolumn{1}{l}{ Rho } & $P$-value \\
\hline Sea ice (JFM) & 0.124 & 0.078 \\
Sea ice (AMJ) & $\mathbf{0 . 1 5 0}$ & $\mathbf{0 . 0 3 2}$ \\
Sea ice (JAS) & 0.131 & 0.063 \\
Sea ice (OND) & 0.011 & 0.878 \\
Sea ice (mean annual) & $\mathbf{0 . 2 0 0}$ & $\mathbf{0 . 0 0 4}$ \\
Ice-free months & $\mathbf{- 0 . 1 5 0}$ & $\mathbf{0 . 0 2 6}$ \\
Air temperatures $(250 \mathrm{~km})$ & -0.073 & 0.369 \\
Air temperatures $(200 \mathrm{~km})$ & -0.070 & 0.409 \\
Air temperatures $(150 \mathrm{~km})$ & 0.007 & 0.923 \\
\hline
\end{tabular}

Results include all of the study glaciers. This was tested for mean seasonal (January-March, April-June, July-September, October-December) and mean annual sea-ice concentrations, and the number of ice-free months. The correlation coefficient was also tested for air temperatures, using a different threshold distance between the meteorological station and the glacier, to ensure that results were independent of the threshold distance used. The $P$-value indicates the significance of the correlation, with $\leq 0.05$ indicating a significant correlation (bold). Rho is the correlation coefficient, and provides a measure of the association between two variables, where 1 is a perfect positive correlation and -1 is a perfect negative correlation. and central-west Greenland, the mean number of ice-free months increased by 1 month, with glaciers in the Qaanaaq region showing the greatest change (Fig. 5). The mean number of ice-free months increased significantly on the Barents coast (mean $=+0.9$ ice-free months) and the Kara Sea (mean $=+1$ months), and increases were much larger on the west coast of Spitzbergen, compared with Austfonna and Vestfonna (Fig. 5; Table 3). Changes were more limited in south-east Greenland, particularly along its northern section, where increases in the mean number of ice-free months were 0.2 months (Fig. 5; Table 3). In East Greenland, the mean number of ice-free months increased from 1.2 to 1.7 months between 1995-99 and 2000-10 (Fig. 5), which was a significant difference (Table 3).

Overall, the mean rate of frontal position change (200010) for each glacier was positively correlated with the magnitude of change in mean annual sea-ice concentrations between 1995-99 and 2000-10 $(\rho=0.20 ; \quad P=0.004)$ (Table 4). This demonstrates that larger reductions in seaice concentrations are associated with higher mean retreat rates, i.e. greater sea-ice loss was associated with more rapid glacier retreat. The mean rate of frontal position change was also significantly positively correlated with spring (AprilJune) sea-ice concentrations $(\rho=0.15 ; P=0.03)$, but no significant relationships were found for the other seasons (Table 4). Finally, the mean rate of a frontal position change for 2000-10 correlated negatively with the number of ice-free months $(\rho=-0.15 ; P=0.03)$, showing that higher retreat rates are associated with greater reductions in the number of ice-free months (Table 4).

\section{Ocean temperatures}

The reanalysis dataset Topaz 4 was used to investigate broadscale ocean temperature changes in the study region (Fig. 8). It should be noted that the data may not accurately capture water temperatures and circulation within glacier fjords, 

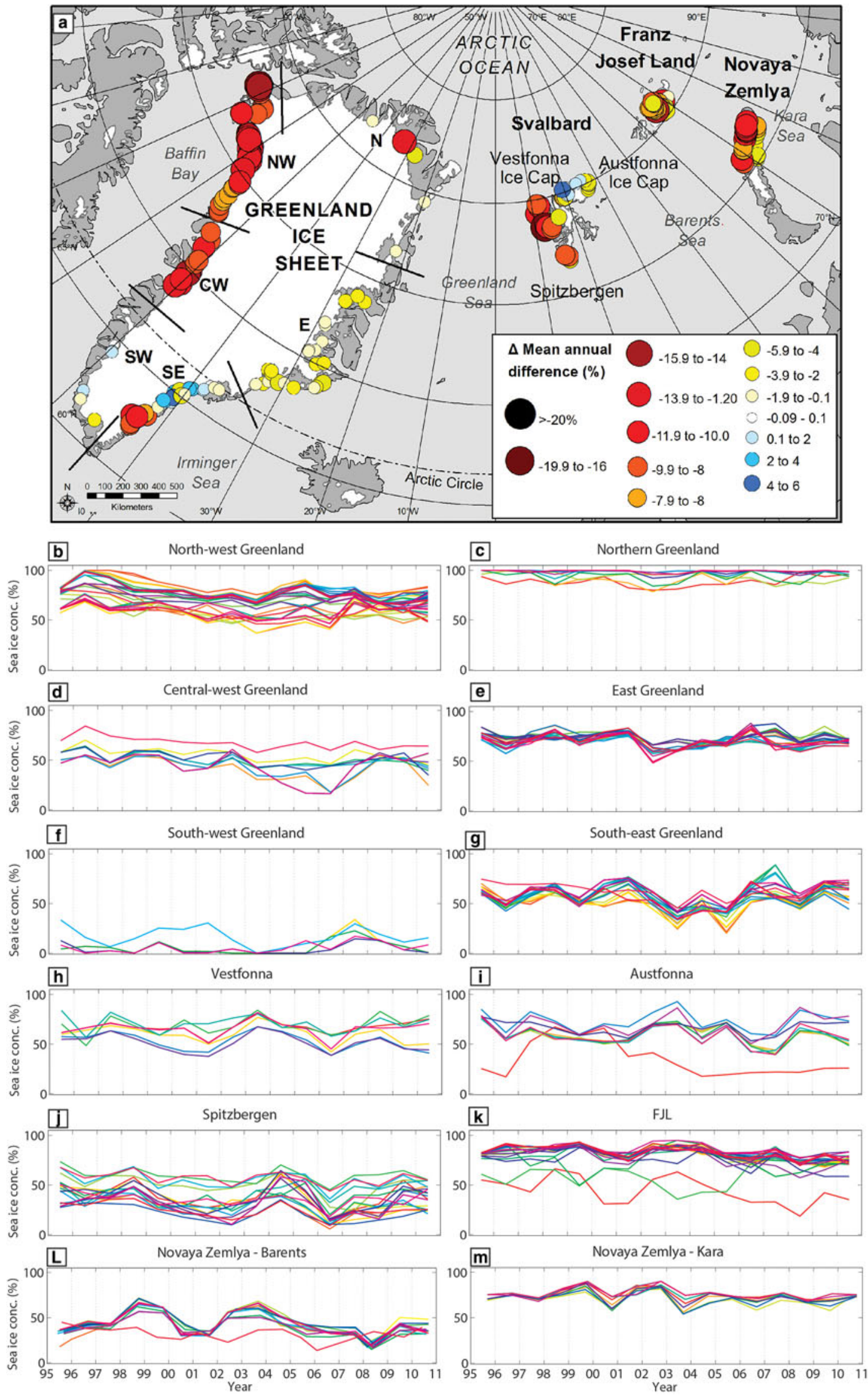

Fig. 4. (a) Difference in mean annual sea-ice concentrations for the period 2000-10, relative to 1995-99. Symbol size and colour show the magnitude of the change in percent (darker red = decreased sea-ice concentration; darker blue $=$ increased sea-ice concentration). $(b-m)$ Time series of the mean annual sea-ice concentrations, for the period 1995-2010, for each study region. 


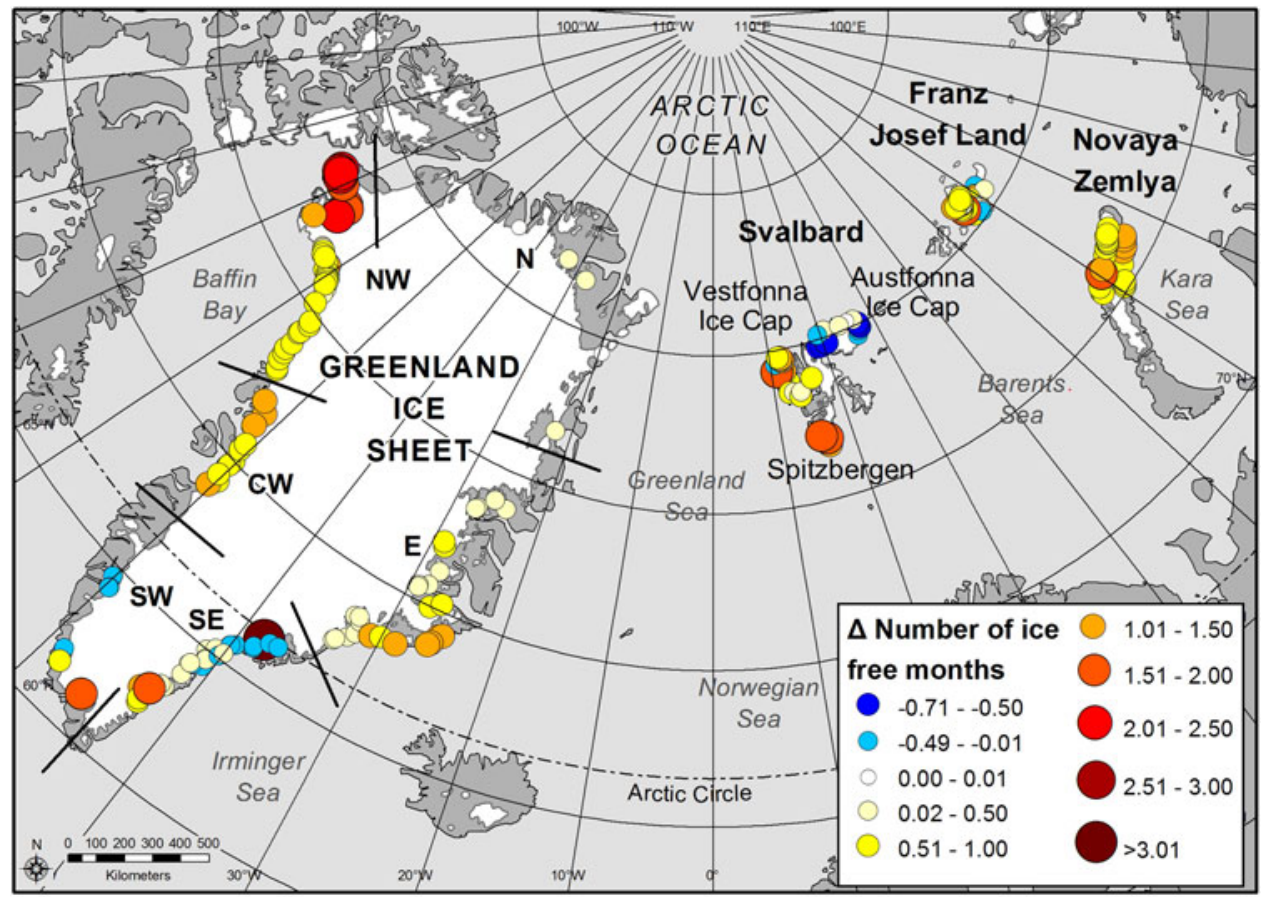

Fig. 5. Change in the mean number of ice-free months for the period 2000-10, relative to 1995-99. Symbol size and colour show the magnitude of the change in months (darker red = greater increase in the number of ice-free months; darker blue = greater reduction in the number of ice-free months).

including fjord stratification and subglacial plumes, which are known to substantially impact melt rates (Jenkins, 2011; Straneo and others, 2011; Straneo and others, 2013). Equally, temperature changes observed at the continental shelf are not necessarily transmitted to glacier termini, as this will depend on the fjord geometry, particularly the presence of shallow sills and/or the grounding line depth (Carroll and others, 2017). However, detailed oceanographic data are only available for a limited number of Arctic outlet glacier fjords and the limited evidence available suggests that offshore water does access Greenlandic glacier fjords (e.g. Holland and others, 2008; Straneo and others, 2010; Straneo and others, 2012). We, therefore, use the reanalysis data as a preliminary exploration of the broad-scale ocean temperature changes within the study area, as opposed to definitive information on the temperature of water reaching the glacier terminus.

The strongest ocean temperature increases between 1991-99 and 2000-10 occurred in the Irminger and Labrador Seas, offshore of south-east and south-west Greenland, where warming reached up to $2.5^{\circ} \mathrm{C}$ (Fig. 8). This is consistent with previous studies, based on direct measurements (e.g. Myers and others, 2007; Yashayaev, 2007; Holliday and others, 2008). More moderate warming in the $5 \mathrm{~m}$ layer also occurred in the north- and central-west Greenland. Within the Greenland Sea and offshore of east Greenland, water at $200 \mathrm{~m}$ depth cooled between 1991-99 and 2000-10 (Fig. 8). It should be noted that this may represent a temperature change, or, alternatively, we may have inadvertently captured changes in the pycnocline depth, but we cannot determine which with the available data. Warming was evident on the west coast of Spitzbergen at both 5 and $200 \mathrm{~m}$ depth and slight cooling occurred offshore of Austfonna (Fig. 8). Finally, the Barents and Kara Sea warmed in the near-surface layer (5 $\mathrm{m}$ depth), but the Kara Sea cooled at $200 \mathrm{~m}$ depth (Fig. 8).

\section{DISCUSSION}

\section{Glacier frontal position versus volumetric loss}

Our results demonstrate that outlet glaciers in the Atlantic Arctic are exhibiting common behaviour at decadal timescales, i.e. high-magnitude (retreat rates exceed $-100 \mathrm{~m}$ $\mathrm{a}^{-1}$ ) and accelerating retreat. This is consistent with the widespread ice-mass loss recorded in the Arctic between 2003 and 2009 (Gardner and others, 2013) and confirms that land ice loss is nearly ubiquitous across the Arctic. High retreat rates in the north-west, central-west and south-east Greenland (Fig. 1, Table 1) are consistent with previously reported patterns of mass loss (van den Broeke and others, 2009) and acceleration (Moon and others, 2012). However, estimated dynamic mass losses from northern Greenland glaciers are small (van den Broeke and others, 2009; Khan and others, 2014; Andersen and others, 2015), compared with the large retreat we report (e.g. Table 1, Fig. 1). This apparently limited dynamic response to retreat contrasts markedly with elsewhere on the Greenland ice sheet (e.g. Pritchard and others, 2009; Thomas and others, 2011) and the impact of ice tongue losses on velocities varies substantially between individual outlets (Moon and others, 2012; Nick and others, 2012). This likely results from the large variation in the amount of resistive stress provided by the floating ice tongues in northern Greenland (Moon and others, 2012; Nick and others, 2012): losses of large floating sections would have a limited impact on ice dynamics if the resistive stresses they provided were low. However, if the tongues provide significant resistive stress and/or lead to loss of grounded ice then the impact on the large reservoirs of inland ice would increase dramatically. This highlights northern Greenland as a priority for future research, as it currently accounts for $40 \%$ of Greenland by area (Rignot and Kanagaratnam, 2006) and therefore has the potential to 


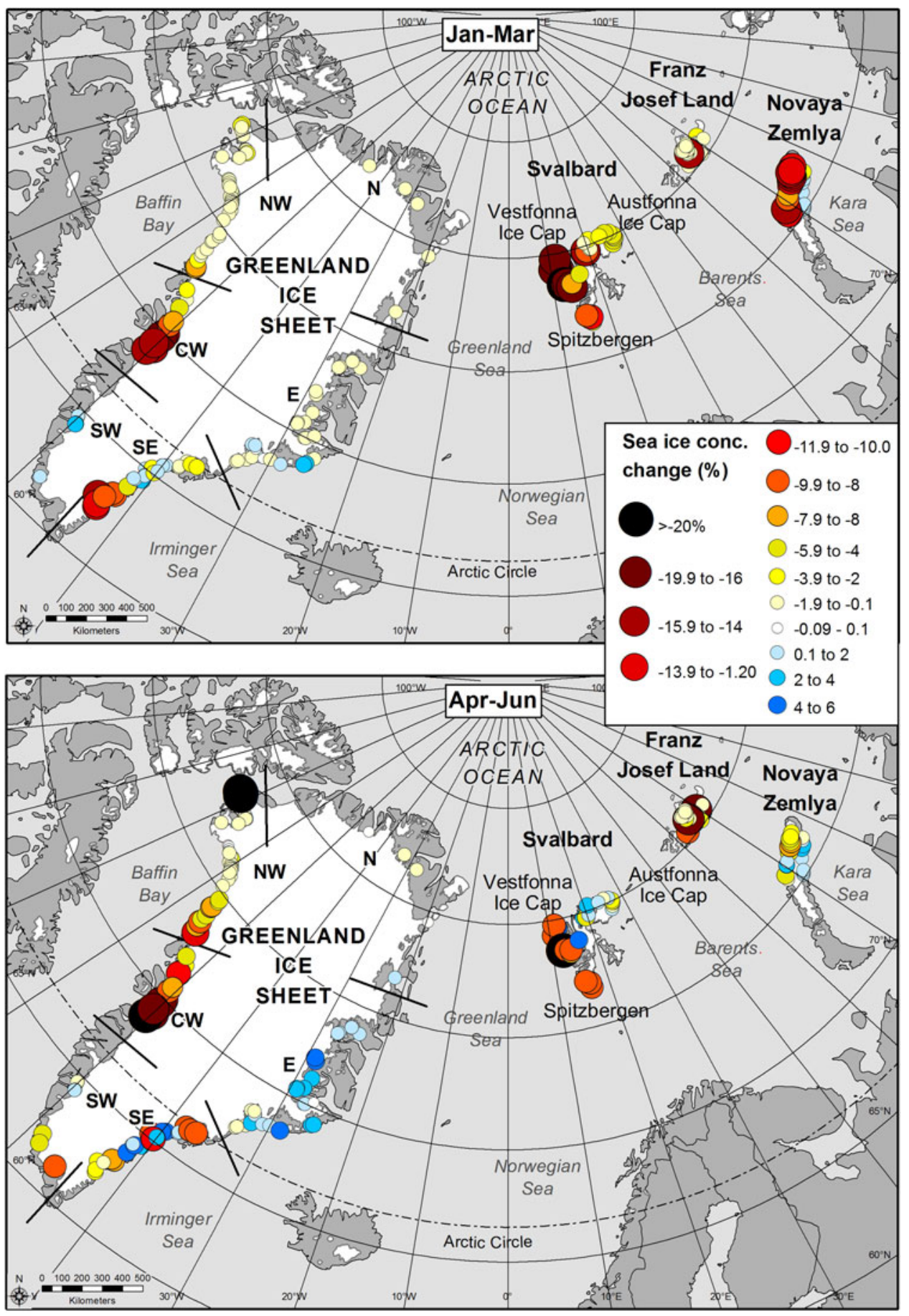

Fig. 6. Difference in mean seasonal sea-ice concentrations for the period 2000-10, relative to 1995-99, for (a) Winter (January-March) and; (b) Spring (April-June). Symbol size and colour show the magnitude of the change in percent (darker red = decreased sea-ice concentration; darker blue $=$ increased sea-ice concentration).

contribute substantially to sea-level rise if grounded ice is lost in the future.

Further work is also required on the Barents Sea coast of Novaya Zemlya, where glaciers are retreating substantially (Fig. 1 \& Table 1). Here, there is a debate about the impact of recent retreat on inland ice dynamics and volumetric losses. Results from ICESat laser altimeter data showed no difference in area-averaged thinning rates and land- and marineterminating outlets glaciers on Novaya Zemlya, despite an order of magnitude difference in retreat rates (Moholdt and others, 2012). Conversely, more recent work recorded much higher thinning rates on marine-terminating glaciers on the Barents Sea coast, compared with those ending on land, suggesting that recent glacier retreat has led to dynamic ice loss and thinning (Melkonian and others, 2016). As such, we highlight the dynamic ice losses from Novaya Zemlya as a key area for future research. On Svalbard, the highest rates of retreat occurred on Spitzbergen (Fig. 1 \& Table 1), which corresponds to the areas where thinning rates were greatest between 2003 and 2008 (Moholdt and others, 2010). In contrast, Vestfonna underwent limited thinning during this time interval (Moholdt and others, 2010) and exhibited the lowest retreat rates in the study area for both 1992-2000 and 2000-10 (Table 1).

For the majority of the study regions, removing outliers from calculations of mean rates of frontal position change 


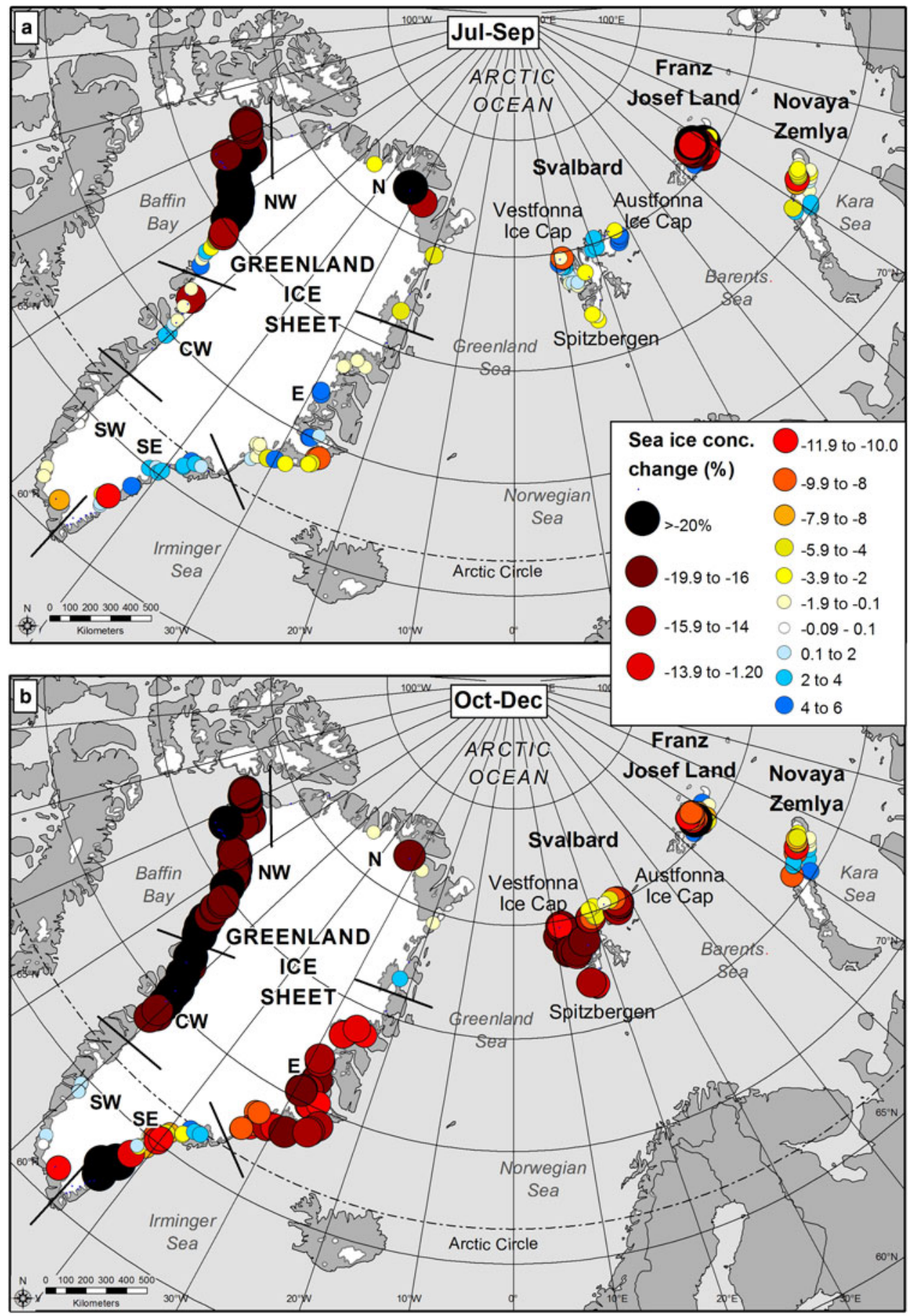

Fig. 7. Difference in mean seasonal sea-ice concentrations for the period 2000-10, relative to 1995-99, for (a) Summer (July-September) and; (b) Autumn (October-December). Symbol size and colour show the magnitude of the change in percent (darker red = decreased sea-ice concentration; darker blue $=$ increased sea-ice concentration).

(1992-2010) had little impact. However, in north-west Greenland regional values were strongly affected by nine glaciers from a population of 55 and the removal of these glaciers reduced the mean regional retreat rate from -115.8 to $-51.3 \mathrm{~m} \mathrm{a}^{-1}$. Some of these outlets (Alison Glacier, Kong Oscar Gletscher, Paarnarsuit Sermiat, Rink Gletsjer, and Sverdrup Gletsjer) have been the focus of previous studies (e.g. Carr and others, 2013b), but others have not been specifically investigated (we here refer to them as NW1, NWG29, NWG2 and NWG11). Strong acceleration has accompanied retreat on a number of these outlets, particularly Alison Glacier, Kong Oscar Gletscher, NWG29, and Sverdrup Gletsjer (Moon and others, 2012). We, therefore, highlight these glaciers as important sites of future research, as they appear to strongly effect mean retreat rates in northwest Greenland and may therefore, contribute disproportionally to future dynamic ice loss.

\section{Climatic and oceanic forcing}

Our results reveal widespread and marked changes in the climatic and oceanic conditions across the Arctic (Figs. 3-8), consistent with previous studies (e.g. Box and others, 2009; Beszczynska-Möller and others, 2012; Hanna and others, 2012; Hanna and others, 2013; Sutherland and others, 2013) and with the amplification of global climate warming 


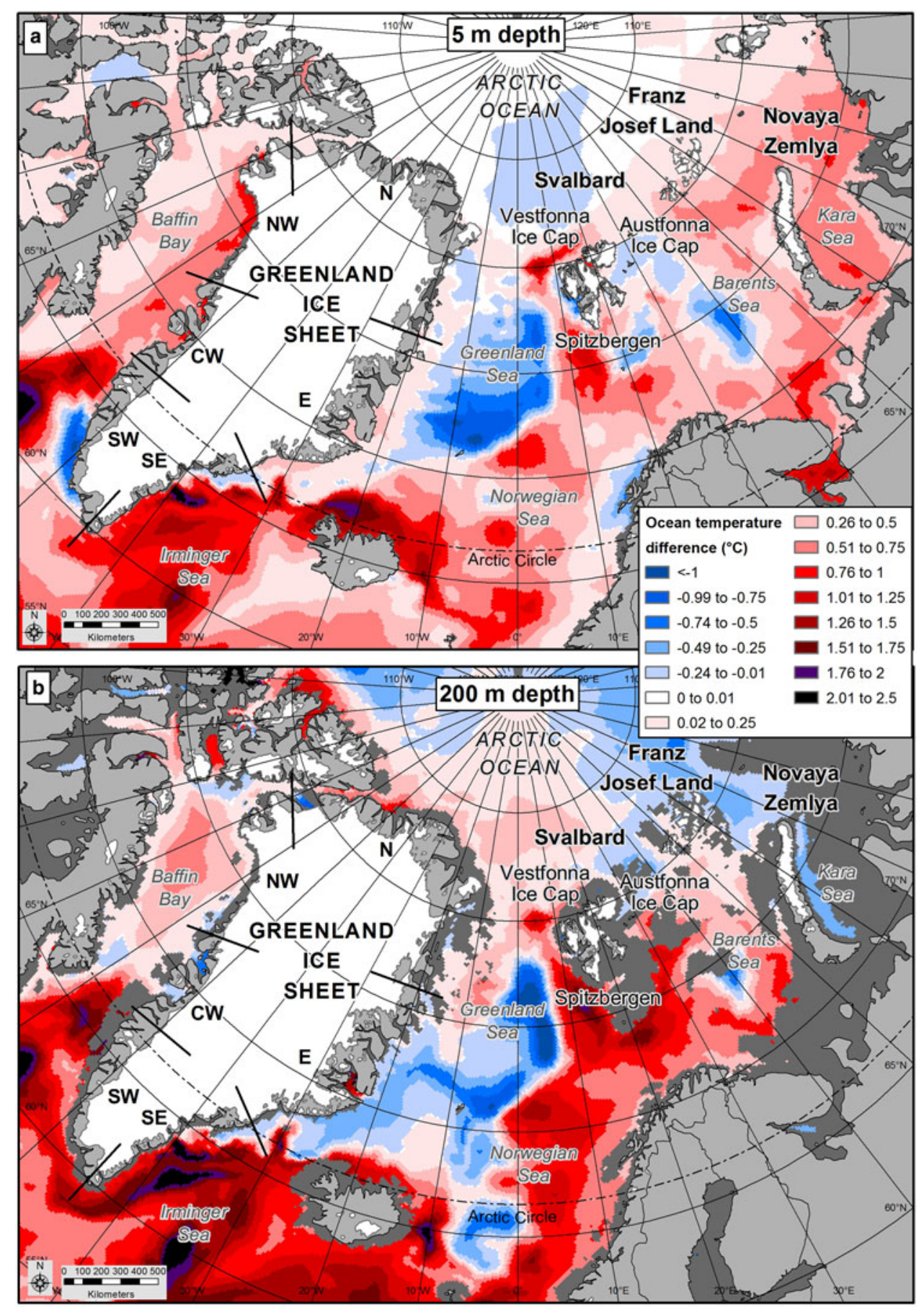

Fig. 8. Difference in mean ocean temperature (from reanalysis data) for the period 2000-10, relative to 1995-99, for (a) $5 \mathrm{~m}$ depth and (b) 200 $\mathrm{m}$ depth. Colour shows the magnitude of the anomaly in ${ }^{\circ} \mathrm{C}$ (darker red = greater warming; darker blue = greater cooling; dark grey $=$ no data). Data are shown for $5 \mathrm{~m}$ (a) and $200 \mathrm{~m}$ (b), to demonstrate changes in temperature in the near-surface layer $(5 \mathrm{~m})$ and the likely upper depth $(200 \mathrm{~m})$ of sub-surface waters (e.g. Atlantic Water) reaching the glacier fronts within the region (e.g. Holland and others, 2008; Straneo and others, 2012).

within the Arctic (IPCC, 2013). This includes summer (JuneAugust) atmospheric warming of up to $2.4^{\circ} \mathrm{C}$, a reduction in mean annual sea-ice concentrations of up to $18 \%$, extension of ice-free conditions by up to 3 months, and oceanic warming of up to $2.5^{\circ} \mathrm{C}$ at depths of 5 and $200 \mathrm{~m}$ (Figs. 3-8).

\section{Air temperatures}

Focusing first on air temperatures, the spatial pattern of glacier retreat and summer atmospheric warming was coincident in certain locations, for example in the north- and central-west Greenland, where temperature increases were highest (Fig. 3). However, this pattern was far from ubiquitous and no clear relationship was apparent between summer air temperature increases and regional-scale glacier rates of glacier frontal position change. For example, retreat rates were higher in south-east Greenland than in the north-west (Table 1), despite warming being stronger in the latter area (Fig. 3). Similarly, summer warming was high in magnitude and significant in south-west Greenland, but glacier retreat rates were much lower than elsewhere on the ice sheet (Fig. 3). Furthermore, there was no significant correlation 
between summer atmospheric warming and individual glacier retreat rates (Table 4), suggesting that there is no straight-forward, direct link between air temperatures and marine-terminating glacier retreat at decadal timescales and the pan-Arctic spatial scale.

In contrast to the relationship between air temperature trends and glacier frontal position change, we find a significant correlation between the rate of glacier frontal position change and changes in the three sea-ice variables we measured between 1995-99 and 2000-10: mean annual sea-ice concentration, mean spring (April-June) sea-ice concentration and number of ice-free months (Table 4). The largest reductions in sea-ice concentrations occurred in north-west Greenland, where significant losses occurred in all seasons of the year (Fig. 5, Table 3). This is consistent with previous, more localised studies (Carr and others, 2013b; Moon and others, 2015) and demonstrates a strong correspondence between sea-ice concentrations and retreat rates in this region. On FJL, significant reductions in sea-ice concentrations occurred in all seasons between 1995-99 and 2000-10 (Table 3, Figs. 6 \& 7). This coincided with glacier retreat rates on the archipelago doubling (Table 1), indicating that sea-ice losses may also be an important influence here. Sea ice has been identified as an important control on the neighbouring ice masses on Novaya Zemlya (Carr and others, 2014), but not previously on FJL. North-west Greenland and FJL were the only locations that underwent significant changes in summer (July-September) sea-ice concentrations (Table 3), most likely due to their northerly location and oceanographic setting: in more southerly areas, sea ice was absent during the summer months for the entire study period, meaning that no changes were observed between the two time steps. In east Greenland, sea-ice losses were significant in October-December (Fig. 6; Table 3), which is when sea ice generally forms in the region and also coincides with previously reported atmospheric warming during these months (Seale and others, 2011). Earlier studies suggested that sea ice may strongly influence glacier retreat rates at Kangerdlugssuaq Glacier (Joughin and others, 2008a; Seale and others, 2011), but has limited impact on DaugaardJensen Gletscher and Storstrømmen (Seale and others, 2011). Given the significant and high magnitude changes in sea ice observed in the region and its apparent influence on glacier behaviour elsewhere in Greenland (Carr and others, 2013b; Moon and others, 2015), this potential control should be assessed in further detail.

\section{Sea ice}

The relationship between sea ice and glacier retreat likely reflects the impact of the seasonal ice mélange on calving rates: when the mélange is in place, it is thought to suppress calving by up to a factor of six, whereas its seasonal disintegration allows high summer calving rates to recommence (Sohn and others, 1998; Joughin and others, 2008b; Amundson and others, 2010; Todd and Christoffersen, 2014; Miles and others, 2017). As a result, extension of the ice-free season (indicated by the number of ice-free months) could increase the duration of seasonally high calving rates and thus promote retreat (Reeh and others, 2001; Carr and others, 2013b; Moon and others, 2015). This extension of the summer calving season could occur via earlier spring sea-ice break-up and/ or later sea-ice formation. The significant correlation between the rates of frontal position change on individual glaciers (2000-10) and the change in spring sea ice indicates that the former may be more important, although the magnitude of sea-ice loss was much greater and more widespread in autumn (Figs. 6 \& 7; Table 4). Our results suggest that Arctic outlet glacier retreat rates may be sensitive to changes in sea-ice concentrations at the beginning/end of summer open water conditions and this warrants further investigation, using higher temporal resolution data. In particular, there is a need to assess variations in the characteristics of the ice mélange, and its relationship to glacier retreat, as this may vary considerably with factors such as fjord geometry and sea-ice conditions.

It has previously been suggested that sea ice strongly controls glacier calving in northern Greenland (Higgins, 1990; Reeh and others, 1999). The only significant change observed here was in winter sea ice (Table 3). However, this was due to a small reduction in mean values for all locations in winter 2007 (from 100 to 92.5\%), which then reduced the 2000-10 mean from 100 to $99.8 \%$, and is thus highly unlikely to have any effect on glacier behaviour. At the same time, large retreats and tongue collapses were observed in northern Greenland (Table 1 \& Fig. 4). On some glaciers, such as Hagen Brae (Supplementary Information Fig. 3), retreat and acceleration (Joughin and others, 2010) coincided with reduced mean annual sea-ice concentrations (Fig. 4). However, this was not a ubiquitous control across northern Greenland, as glaciers such as C.H. Ostenfeld underwent comparable retreat (Supplementary Information Fig. 3), even with the presence of fast-ice. Sea ice, therefore, appears to play a variable role in northern Greenland. Indeed, our results show limited changes in air temperatures or sea-ice conditions in northern Greenland, despite the major tongue collapses. The ocean reanalysis data suggest a statistically significant warming of $0.25^{\circ} \mathrm{C}$ in the region between $1991-99$ and $2000-10$ (Fig. 8). This should be interpreted with strong caution, as the reanalysis data have limited constraints from observational data in this area. However, even a small temperature increase, such as this, would have a large impact, as basal melting across the large floating ice tongues is a primary component of mass loss in the area and could promote rapid retreat via thinning and/ or basal melt channel formation (Reeh and others, 1999; Rignot and Steffen, 2008). This highlights the urgent need to collect oceanic temperature data from northern Greenland, as it is undergoing widespread tongue collapse and retreat, without a clear cause.

\section{Ocean temperatures}

We use Topaz reanalysis data to identify broad-scale changes in ocean temperatures at depths of 5 and $200 \mathrm{~m}$ (Fig. 8). It should be noted that these data are not necessarily representative of conditions at the glacier front, due to complexities in fjord circulation, including subglacial plume flow, and the potential presence of bedrock sills, which may limit or preclude offshore water from reaching the glacier front. However, previous studies have indicated that oceans exert an important influence on Arctic glacier retreat rates (e.g. Holland and others, 2008; Murray and others, 2010; Luckman and others, 2015) and directlymeasured data are only available for a small number of glacial fjords and for short-time periods. We, therefore, use the data as a guide to the changes in the offshore water masses and comment on how this would affect the glaciers if it were to reach the glacier front. 
Observed ocean warming offshore of south-east and western Greenland (Fig. 8) is likely to be associated with well-documented changes in the sub-polar gyre and Irminger Current, which began in the mid-1990s and then propagated to the west Greenland coast within the West Greenland Current (Stein, 2005; Myers and others, 2007; Holliday and others, 2008). If this warming were transmitted to the glacier front, it would increase sub-surface melt rates substantially and has previously been identified as a probable trigger for observed retreat in south-east Greenland (Howat and others, 2008; Murray and others, 2010; Christoffersen and others, 2011). Although our data show strong warming offshore of south-west Greenland during the 2000s (Fig. 8), which agrees with direct measurements (e.g. Ribergaard and others, 2008), glacier retreat in the region was limited (Fig. $1 \&$ Table 1). Many of the glaciers in the region are located at the end of long, sinuous fjords (e.g. Kangiata Nunata Sermia and Akugdlerssup Sermia), which may reduce the impact of any offshore warming, although recent numerical modelling results from east Greenland suggest that sub-surface inputs of glacial runoff can allow warm coastal water to penetrate into fjords $\sim 100 \mathrm{~km}$ long (Cowton and others, 2016). Our data indicate that oceanic warming reached central-west Greenland by 1997, which is consistent with direct measurements (Holland and others, 2008), and may have promoted retreat through both enhanced submarine melt and the observed decline in sea-ice concentrations.

On Novaya Zemlya, differences in the pattern of sea ice decline and oceanic warming between the Barents and Kara Sea coasts may explain the difference in retreat rates (Table 1): in the Barents Sea, significant warming occurred at $5 \mathrm{~m}$ and $200 \mathrm{~m}$, and significant sea-ice reductions occurred in winter, spring and annual means (Table 3). Conversely, no warming was apparent in the Kara Sea at depth, and, although changes in mean annual sea-ice concentrations were significant (Table 3), they were much smaller in magnitude than on the Barents Sea coast (Fig. 4). Across Novaya Zemlya, retreat rates between 1992 and 2010 were an order of magnitude greater on marine-terminating glaciers than those ending on land (Carr and others, 2014), suggesting an oceanic cause for retreat. Furthermore, directly measured data show that warm Atlantic water $\left(3.6^{\circ} \mathrm{C}\right)$ can penetrate into at least one glacier fjord on the Barents Sea coast (Politova and others, 2012). Summer air temperatures did not warm significantly between 1991-99 and 2000-10 (Table 3). As such, available evidence suggests that oceanic forcing (both ocean temperatures and sea-ice concentrations) may influence glacier retreat rates on Novaya Zemlya. However, even fewer direct measurements are available from Novaya Zemlya fjords than in Greenland, and so more in situ data are needed to fully understand the causes of glacier retreat in the region.

\section{Differences in the response of individual glaciers to external forcing}

Our results show a significant correlation between rates of frontal position change on individual glaciers and changes in mean annual sea-ice concentrations $(\rho=0.20 ; P=0.004)$, spring (April-June) sea-ice concentrations $(\rho=0.15 ; P=$ $0.03)$, and the number of ice-free months $(\rho=-0.15$; $P=0.03$ ) (Table 4). However, despite being significant, the correlation coefficients $(\rho)$ are comparatively weak. We suggest three potential explanations for this, which are not mutually exclusive: (i) retreat rates are also influenced by shorter-term, more step-like changes in forcing; (ii) that the magnitude of glacier retreat is strongly influenced by glacier specific factors; and/or (iii) that factors correlated with both sea ice and glacier frontal position are also playing a role, e.g. ocean temperatures. Previous studies have suggested that short transient periods of oceanic and/or atmospheric warming, as opposed to multi-annual trends, can be the initial trigger for glacier retreat (e.g. Holland and others, 2008; Howat and others, 2008; Christoffersen and others, 2011). However, this is challenging to analyse at the scale of the Atlantic Arctic and with a large population of study glaciers. Furthermore, it has important implications for predictions of future warming and its impact on ice loss, which are often made at decadal to centennial timescales.

The second possibility is that changes in climatic/oceanic conditions are the initial trigger for glacier retreat, but the magnitude of that retreat on any given glacier depends on local factors (e.g. fjord topography). This explanation is supported by the much greater variability we observed in rates of frontal position change, compared with the variability in external controls, within each region (e.g. Figs. 6 \& 7 cf. Supplementary Fig. 3). It is also strongly supported by the significant, strong correlation between fjord width variability along the glacier's retreat path and total retreat rates (19922010) $\left(\rho=-0.570 ; P\right.$-value $\left.=1.20 \times 10^{-19}\right)($ Table 2$)$. This indicates that retreat rates were higher when larger variations in fjord width occurred along the glacier's retreat path (Table 2) and data show that this is generally associated with recession into a widening section of the fjord: $67 \%$ of glaciers with a fjord width variability value of 1.05 or greater retreated into a wider fjord. Furthermore, retreat rates were substantially higher on glaciers retreating into wider fjords $\left(-147.4 \mathrm{~m} \mathrm{a}^{-1}\right)$, than those retreating into narrow or straight fjords $\left(-60.1 \mathrm{~m} \mathrm{a}^{-1}\right)$. This upstream fjord widening enhances glacier retreat via two mechanisms: (i) the ice is spread over a larger area and so must thin (O'Neel and others, 2005) (due to mass conservation), making it more vulnerable to fracture and retreat through calving; (ii) the resistance to flow provided by the fjord walls decreases with fjord width (Raymond, 1996), meaning that ice moving into a wider fjord experiences less resistance to flow and retreats more rapidly. The influence of fjord width variation was greatest where outlet glaciers flowed through well-defined fjords (western and east Greenland, Novaya Zemlya and Spitsbergen), which accounted for the majority of our study glaciers (197 out of 212) (Table 2). It was least where glaciers are bounded by slower moving ice (Austfonna and Vestfonna), where sudden changes in fjord width are rare (Table 2). Thus climatic/oceanic changes may be the initial trigger of retreat, but fjord topography, which we quantify here through along-fjord width variability, appears to strongly influence the magnitude of retreat on individual glaciers. It may also explain the large variability in individual glacier retreat rates that we see within regions (Supplementary Figs. 3-6).

Northern Greenland is an exception to this relationship and retreat rates show no apparent correspondence to fjord width variations (Table 2). Here, glaciers such as Peterman Glacier (Nick and others, 2012) and C.H. Ostenfeld Glacier (Joughin and others, 2010) have large floating ice tongues that are thin and fractured and would therefore, provide little lateral resistance. Similarly, the friction provided by the fjord walls 
would have limited influence on ice flow for very wide outlets such as Humboldt (width $=\sim 90 \mathrm{~km}$ ) and 79 North Glacier (width $=\sim 34 \mathrm{~km}$ ). Basal topography is also known to promote rapid retreat on individual glaciers, but it is much more difficult to quantify. Therefore, although fjord width variability is not a substitute for knowing the full 3-D bathymetry of the glacier fjord and retreat is likely to also be influenced by basal topography, it may provide a widelyapplicable and easily-measurable indicator of individual marine-terminating glaciers with grounded termini that have the potential for high retreat rates. It should be noted that no clear relationship exists for glaciers with floating termini. The metric can be used where detailed bathymetric data are unavailable, which is the case for the majority of Arctic outlet glacier fjords.

Our results demonstrate that Arctic outlet glaciers are exhibiting similar behaviour (i.e. widespread, substantial retreat) at the broadest temporal and spatial scales and also show relationships between retreat and external factors at these scales. We identify the regions and individual glaciers that have undergone the greatest net retreat in recent years, and these locations should be the focus of more detailed study, in order to determine the exact timing and pattern of retreat. Similarly, we assess glacier sensitivity to external controls at a necessarily coarse temporal resolution and identify sea-ice concentrations at the start and/or end of open water conditions as a potentially widespread control, highlighting this is a topic for more detailed investigation. Future work should collect higher-temporal resolution data on both retreat and external controls at the most rapidly retreating glaciers, in order to determine how broader-scale changes in external controls are translated into the local-scale process of retreat. In addition, results suggest that fjord geometry strongly modulates individual glacier response to forcing, and so glaciers with geometries that may promote more rapid retreat (fjord widening and or deepening inland) should also be the focus of further investigation. In order to comprehensively investigate this, we need to collect high-resolution information on basal topography and fjord bathymetry, particularly in areas where it is currently lacking (e.g. Novaya Zemlya). Finally, we need to combine frontal position data with information on ice velocities, in order to determine how glacier calving fluxes have changed across the Arctic over time and the impact of these dynamic changes on the overall mass loss.

\section{CONCLUSIONS}

Marine-terminating outlet glaciers are exhibiting common behaviour across the Atlantic Arctic at decadal timescales, i.e. high-magnitude and accelerating retreat. Retreat rates increased by a factor of 3.5 between 1992-2000 and 2000-10, with $97 \%$ of all study glaciers retreating during the latter period. Regions with the most pronounced retreat are located in northern, western and south-eastern Greenland and western Novaya Zemlya. Nine glaciers contributed strongly to retreat rates in north-west Greenland, making these outlets key sites for future study. Summer atmospheric warming does not show a simple relationship with patterns of retreat across the Arctic and does not correlate with individual glacier retreat rates. Reanalysis data indicate substantial offshore warming in the 2000s, particularly in southern Greenland (200 m depth), and cooling in east Greenland and the Kara Sea. This suggests that substantial changes in the ocean occurred during the study period, which is consistent with direct measurements in the offshore ocean; however, data are required from within glacial fjords, to assess the extent to which these offshore oceanic changes are transmitted to the glacier front. At decadal timescales, changes in mean annual and spring (April-June) sea-ice concentrations and the number of ice-free months correlated significantly, but weakly, with individual glacier retreat. This suggests that controls on the duration of seasonally high calving rates are an important influence on glacier retreat rates in the Atlantic Arctic, but that the magnitude of glacier retreat may also be strongly affected by glacier specific factors. Irrespective of the initial external trigger, the pattern, rate and magnitude of the retreat of an individual glacier is strongly modulated by local factors and fjord width variability may provide a widely-applicable indicator for rapid retreat. Despite an overall common behaviour across the Atlantic Arctic, the modulation of individual glacier response to forcing by its local characteristics introduces considerable complexity when attempting to predict its detailed response to future climate change.

\section{ACKNOWLEDGEMENTS}

This work was supported by a Durham Doctoral Studentship, granted to J.R. Carr. Envisat and ERS Image Mode Precision scenes were provided by the European Space Agency (ESA). We thank the anonymous reviewers for their helpful comments.

\section{SUPPLEMENTARY MATERIAL}

The supplementary material for this article can be found at https://doi.org/10.1017/aog.2017.3

\section{REFERENCES}

Amundson JM and 5 others (2010) Ice mélange dynamics and implications for terminus stability, Jakobshavn Isbræ, Greenland. J. Geophys. Res., 115, F01005

Andersen ML and 9 others (2015) Basin-scale partitioning of Greenland ice sheet mass balance components (2007-2011). Earth Planet. Sci. Lett., 409, 89-95

Bartholomaus TC and 10 others (2016) Contrasts in the response of adjacent fjords and glaciers to ice-sheet surface melt in west Greenland. Ann. Glaciol., 57(73) 1-14

Benn DI, Warren CR and Mottram RH (2007) Calving processes and the dynamics of calving glaciers. Earth Sci. Rev., 82, 143-179

Beszczynska-Möller A, Fahrbach E, Schauer U and Hansen E (2012) Variability in Atlantic water temperature and transport at the entrance to the Arctic Ocean, 1997-2010. ICES J. Mar. Sci. 69 (5), 852-863

Blaszczyk M, Jania JA and Hagen JM (2009) Tidewater glaciers of Svalbard: recent changes and estimates of calving fluxes. Pol. Polar Res., 30(2), 85-142

Box JE, Yang L, Bromwich DH and Bai LS (2009) Greenland ice sheet surface Air temperature variability: 1840-2007. J. Clim., 22, 4029-4049

Cappelen J (2011) Technical report 11-05: dMI monthly climate data collection 1768-2010. The Faroe Islands and Greenland Danish Meteorological Institute, Denmark

Carr JR, Stokes CR and Vieli A (2013a) Recent progress in understanding marine-terminating Arctic outlet glacier response to climatic and oceanic forcing: twenty years of rapid change. Prog. Phys. Geograph., 37(4), 435-466

Carr JR, Vieli A and Stokes CR (2013b) Climatic, oceanic and topographic controls on marine-terminating outlet glacier behavior in 
north-west Greenland at seasonal to interannual timescales. J. Geophys. Res., 118(3), 1210-1226

Carr JR, Stokes C and Vieli A (2014) Recent retreat of major outlet glaciers on Novaya Zemlya, Russian Arctic, influenced by fjord geometry and sea-ice conditions. J. Glaciol., 60, 155-170

Carr JR and 9 others (2015) Basal topographic controls on rapid retreat of humboldt glacier, northern Greenland. J. Glaciol., 61 (225), 137-150

Carroll D and 5 others (2017) Subglacial discharge-driven renewal of tidewater glacier fjords. J. Geophys. Res.: Oceans, 122(8), 6611-6629

Cassotto R, Fahnestock M, Amundson JM, Truffer $M$ and Joughin I (2015) Seasonal and interannual variations in ice melange and its impact on terminus stability, Jakobshavn Isbræ, Greenland. J. Glaciol., 61(225), 76-88

Christoffersen P and 7 others (2011) Warming of waters in an East Greenland fjord prior to glacier retreat: mechanisms and connection to large-scale atmospheric conditions. Cryosphere, 5, 701-714

Cowton T and 5 others (2016) Controls on the transport of oceanic heat to Kangerdlugssuaq glacier, East Greenland. J. Glaciol, 62 (236), 1167-1180

Enderlin EM, Howat IM and Vieli A (2013) High sensitivity of tidewater outlet glacier dynamics to shape. Cryosphere, 7(3), 1007-1015

Enderlin EM and 5 others (2014) An improved mass budget for the Greenland ice sheet. Geophys. Res. Lett., 41(3), 2013GL059010

Fürst JJ, Goelzer H and Huybrechts P (2015) Ice-dynamic projections of the Greenland ice sheet in response to atmospheric and oceanic warming. Cryosphere, 9(3), 1039-1062

Gardner A and 15 others (2013) A reconciled estimate of glacier contributions to Sea level rise: 2003 to 2009. Science, 340 (6134), 852-857

Grant KL, Stokes CR and Evans IS (2009) Identification and characteristics of surge-type glaciers on Novaya Zemlya, Russian Arctic. J. Glaciol., 55(194), 960-972

Hanna E, Mernild SH, Cappelen J and Steffen K (2012) Recent warming in Greenland in a long-term instrumental (18812012) climatic context: I. Evaluation of surface air temperature records. Environ. Res. Lett., 7(4), 045404

Hanna E and 6 others (2013) The influence of North Atlantic atmospheric and oceanic forcing effects on 1900-2010 Greenland summer climate and ice melt/runoff. Int. J. Climatol., 33(4), 862-880

Higgins AK (1990) North Greenland glacier velocities and calf ice production. Polarforschung, 60(1), 1-23

Holland DM, RHDY Thomas B, Ribergaard MH and Lyberth B (2008) Acceleration of Jakobshavn Isbræ triggered by warm subsurface ocean waters. Nat. Geosci., 1, 1-6

Holliday NP and 10 others (2008) Reversal of the 1960s to 1990s freshening trend in the northeast North Atlantic and Nordic seas. Geophys. Res. Lett., 35, L03614

Howat IM and Eddy A (2011) Multi-decadal retreat of Greenland's marine-terminating glaciers. J. Glaciol., 57(203), 389-396

Howat IM, Joughin I, Fahnestock M, Smith BE and Scambos T (2008) Synchronous retreat and acceleration of southeast Greenland outlet glaciers 2000-2006; Ice dynamics and coupling to climate. J. Glaciol., 54(187), 1-14

IPCC (2013) Climate Change 2013: The Physical Science Basis. Working Group I Contribution to the IPCC 5th Assessment Report. Online unedited version

Jamieson SSR and 6 others (2012) Ice stream stability on a reverse bed slope. Nat. Geosci., 5, 799-802

Jenkins A (2011) Convection-Driven melting near the grounding lines of Ice shelves and tidewater glaciers. J. Phys. Oceanogr., 41, 2279-2294

Jensen TS, Box JE and Hvidberg CS (2016) A sensitivity study of annual area change for Greenland ice sheet marine terminating outlet glaciers: 1999-2013. J. Glaciol., 62(231), 72-81
Jiskoot H, Murray T and Luckman A (2003) Surge potential and drainage-basin characteristics in east Greenland. Ann. Glaciol., 36, 142-148

Johnson HL, Münchow A, Falkner KK and Melling H (2011) Ocean circulation and properties in petermann fjord, Greenland. J. Geophys. Res., 116, C01003

Joughin I and 8 others (2008a) Ice-front variation and tidewater behaviour on Helheim and Kangerdlugssuaq glaciers, Greenland. J. Geophys. Res., 113, F01004

Joughin I and 7 others (2008b) Continued evolution of Jakobshavn Isbrae following its rapid speedup. J. Geophys. Res., 113, F04006

Joughin I, Smith B, Howat IM, Scambos T and Moon T (2010) Greenland flow variability from ice-sheet-wide velocity mapping. J. Glaciol., 56(197), 415-430

Khan SA, Wahr J, Bevis M, Velicogna I and Kendrick E (2010) Spread of ice mass loss into northwest Greenland observed by GRACE and GPS. Geophys. Res. Lett., 37, L06501

Khan SA and 9 others (2014) Sustained mass loss of the northeast Greenland ice sheet triggered by regional warming. Nat. Clim. Change, 4(4), 292-299

Luckman A and 5 others (2015) Calving rates at tidewater glaciers vary strongly with ocean temperature. Nat. Commun., 6, 8566

McFadden EM, Howat IM, Joughin I, Smith B and Ahn Y (2011) Changes in the dynamics of marine terminating outlet glaciers in west Greenland (2000-2009). J. Geophys. Res., 116, F02022

Melkonian AK, Willis MJ, Pritchard ME and Stewart AJ (2016) Recent changes in glacier velocities and thinning at Novaya Zemlya. Remote Sens. Environ., 174, 244-257

Miles BW, Stokes CR and Jamieson SS (2017) Simultaneous disintegration of outlet glaciers in porpoise Bay (wilkes land), East Antarctica, driven by sea ice break-up. Cryosphere, 11(1), 427442

Miles BWJ, Stokes CR, Vieli A and Cox NJ (2013) Rapid, climatedriven changes in outlet glaciers on the pacific coast of East Antarctica. Nature, 500(7464), 563-566

Moholdt G, Nuth C, Hagen JO and Kohler J (2010) Recent elevation changes of Svalbard glaciers derived from ICESat laser altimetry. Remote Sens. Environ., 114, 2756-2767

Moholdt G, Wouters B and Gardner AS (2012) Recent mass changes of glaciers in the Russian high Arctic. Geophys. Res. Lett., 39, L10502

Moon T and Joughin I (2008) Changes in ice-front position on Greenland's outlet glaciers from 1992 to 2007. J. Geophys. Res., 113, F02022

Moon T, Joughin I, Smith BE and Howat IM (2012) 21st-Century evolution of Greenland outlet glacier velocities. Science, 336(6081), 576-578

Moon T, Joughin I and Smith BE (2015) Seasonal to multiyear variability of glacier surface velocity, terminus position, and sea ice/ice mélange in northwest Greenland. J. Geophys. Res.: Earth Surf., 120(5), 818-833

Motyka RJ and 5 others (2011) Submarine melting of the 1985 Jakobshavn Isbræ floating tongue and the triggering of the current retreat. J. Geophys. Res., 166, F01007

Murray T (2015) Extensive retreat of Greenland tidewater glaciers, 2000-2010. Arct., Antarct., Alpine Res., 47(3), 427-447

Murray T and 10 others (2010) Ocean regulation hypothesis for glacier dynamics in southeast Greenland and implications for ice sheet mass changes. J. Geophys. Res., 115, F03026

Myers PG, Kulan N and Ribergaard MH (2007) Irminger water variability in the west Greenland current. Geophys. Res. Lett., 34, L17601

Nick FM and 7 others (2012) The response of petermann glacier, Greenland, to large calving events, and its future stability in the context of atmospheric and oceanic warming. J. Glaciol., 58 (208), 229-239

Nick FM and 7 others (2013) Future sea-level rise from Greenland's main outlet glaciers in a warming climate. Nat., 497(7448), 235238 
Nuth C, Kohler J, Aas HF, Brandt O and Hagen JO (2007) Glacier geometry and elevation changes on Svalbard (1936-90): a baseline dataset. Ann. Glaciol., 46(1), 106-116

Nuth C, Moholdt G, Kohler J, Hagen JO and Kääb A (2010) Svalbard glacier elevation changes and contribution to sea level rise. J. Geophys. Res., 115, F01008

O'Neel S, Pfeffer WT, Krimmel R and Meier M (2005) Evolving force balance at Columbia glacier, Alaska, during its rapid retreat. J. Geophys. Res., 110, F03012

Politova NV, Shevchenko VP and Zernova VV (2012) Distribution, composition, and vertical fluxes of particulate matter in bays of Novaya Zemlya archipelago, Vaigach Island at the End of summer. Adv. Meteorol., 2012, 15

Porter DF and 6 others (2014) Bathymetric control of tidewater glacier mass loss in northwest Greenland. Earth Planet. Sci. Lett., 401, 40-46

Pritchard HD, Arthern RJ, Vaughan DG and Edwards LA (2009) Extensive dynamic thinning on the margins of the Greenland and Antarctic ice sheets. Nature, 461, 971-975

Raymond C (1996) Shear margins in glaciers and ice sheets. J. Glaciol., 42(140), 90-102

Reeh N, Mayer C, Miller H, Thomsen HH and Weidick A (1999) Present and past climate control on fjord glaciations in Greenland: implications for IRD-deposition in the sea. Geophys. Res. Lett., 26(8), 1039-1042

Reeh N, Thomsen HH, Higgins AK and Weidick A (2001) Sea ice and the stability of north and northeast Greenland floating glaciers. Ann. Glaciol., 33, 474-480

Ribergaard MH and Buch E (2008) Oceanographic Investigations off West Greenland 2007. NAFO Science Council Document: 7 (003) (www.ocean.dmi.dk/staff/mhri/Docs/scr09-003.pdf).

Rignot E and Kanagaratnam P (2006) Changes in the velocity structure of the Greenland Ice sheet. Science, 311(5763), 986-990

Rignot E and Steffen K (2008) Channelized bottom melting and stability of floating ice shelves. Geophys. Res. Lett., 35, L02503

Rignot E, Koppes M and Velicogna I (2010) Rapid submarine melting of the calving faces of West Greenland glaciers. Nat. Geosci., 3, 187-191

Schild KM and Hamilton GS (2013) Seasonal variations of outlet glacier terminus position in Greenland. J. Glaciol., 59(216), 759-770

Seale A, Christoffersen P, Mugford R and O'Leary M (2011) Ocean forcing of the Greenland ice sheet: calving fronts and patterns of retreat identified by automatic satellite monitoring of eastern outlet glaciers. J. Geophys. Res., 116(F3), F03013
Shepherd A and 46 others (2012) A reconciled estimate of ice-sheet mass balance. Science, 338(6111), 1183-1189

Sohn HG, Jezek KC and van der Veen CJ (1998) Jakobshavn glacier, West Greenland: 30 years of spacebourne observations. Geophys. Res. Lett., 25(14), 2699-2702

Stein M (2005) North Atlantic subpolar gyre warming-impacts on Greenland offshore waters. J. Northwest Atlantic Fisheries Sci., 36, 43-54

Straneo F and 7 others (2010) Rapid circulation of warm subtropical waters in a major glacial fjord in East Greenland. Nat. Geosci., 3, 182-186

Straneo F and 6 others (2011) Impact of fjord dynamics and glacial runoff on the circulation near helheim glacier. Nat. Geosci., 4, $322-327$

Straneo F and 8 others (2012) Characteristics of ocean waters reaching Greenland's glaciers. Ann. Glaciol., 53(60), 202-210

Straneo F and 15 others (2013) Challenges to understanding the dynamic response of Greenland's marine terminating glaciers to oceanic and atmospheric forcing. Bull. Am. Meteorol. Soc., 94(8), 1131-1144

Sund M, Eiken T, Hagen JO and Kääb A (2009) Svalbard surge dynamics derived from geometric changes. Ann. Glaciol., 50, 50-60

Sutherland DA and 5 others (2013) Atlantic water variability on the SE Greenland shelf and its relationship to SST and bathymetry. J. Geophysi. Res.-Oceans, 118(2), 847-855

Thomas RH and 8 others (2011) Accelerating ice loss from the fastest Greenland and Antarctic glaciers. Geophys. Res. Lett., 38, L10502

Todd J and Christoffersen P (2014) Are seasonal calving dynamics forced by buttressing from ice mélange or undercutting by melting? Outcomes from full-stokes simulations of store glacier, West Greenland. Cryosphere, 8(6), 2353-2365

van den Broeke $M$ and 8 others (2009) Partitioning recent Greenland mass loss. Science, 326, 984-986

van den Broeke MR and 7 others (2016) On the recent contribution of the Greenland ice sheet to sea level change. Cryosphere, 10(5), 1933-1946

Vieli A and Nick FM (2011) Understanding and modelling rapid dynamic changes of tidewater outlet glaciers: issues and implications. Surv. Geophys., 32, 437-485

Warren CR and Glasser NF (1992) Contrasting response of south Greenland glaciers to recent climatic change. Arct. Alp. Res., 24(2), 124-132

Yashayaev I (2007) Hydrographic changes in the labrador Sea, 1960- 2005. Prog. Phys. Oceanogr., 73, 242-276 